\title{
Recovery of Neurofilament Expression Selectively in Regenerating Reticulospinal Neurons
}

\author{
Alan J. Jacobs, Gary P. Swain, Joseph A. Snedeker, Donald S. Pijak, Laura J. Gladstone, and \\ Michael E. Selzer \\ Department of Neurology and David Mahoney Institute for Neurological Sciences, University of Pennsylvania Medical \\ Center, Philadelphia, Pennsylvania 19104-4283
}

During regeneration of lamprey spinal axons, growth cones lack filopodia and lamellipodia, contain little actin, and elongate much more slowly than do typical growth cones of embryonic neurons. Moreover, these regenerating growth cones are densely packed with neurofilaments (NFs). Therefore, after spinal hemisection the time course of changes in NF mRNA expression was correlated with the probability of regeneration for each of 18 identified pairs of reticulospinal neurons and 12 cytoarchitectonic groups of spinal projecting neurons. During the first 4 weeks after operation, NF message levels were reduced dramatically in all axotomized reticulospinal neurons, on the basis of semiquantitative in situ hybridization for the single lamprey NF subunit (NF-180). Thereafter, NF expression returned toward normal in neurons whose axons normally regenerate beyond the transection but remained depressed in poorly regenerating neurons. The recovery of NF expression in good regenerators was independent of axon growth across the lesion, because excision of a segment of spinal cord caudal to the transection site blocked regeneration but did not prevent the return of NF-180 mRNA. The early decrease in NF mRNA expression was not accompanied by a reduction in NF protein content. Thus the axotomy-induced loss of most of the axonal volume resulted in a reduced demand for NF rather than a reduction in volume-specific NF synthesis. We conclude that the secondary upregulation of NF message during axonal regeneration in the lamprey CNS may be part of an intrinsic growth program executed only in neurons with a strong propensity for regeneration.

Key words: regeneration; neurofilaments; lamprey; spinal transection; reticulospinal; Müller cells; Mauthner cells; cytoskeleton

Because NFs are more densely packed in regenerating lamprey growth cones than in the axon proximally, we have suggested that transport of NFs into the growth cone might play an active role in the mechanism of regeneration (Pijak et al., 1996). Growth cones of adult mouse retinal cells regenerating in vitro are also filled with NFs (Bates and Meyer, 1993). Moreover, in retinal ganglion cells regenerating into peripheral nerve grafts, axonal transport rates for NF doubled (McKerracher et al., 1990), despite a reduction in NF mRNA (Hoffman et al., 1993; McKerracher et al., 1993b). In goldfish, the expression of mRNA for the NF ON-1 increased during optic nerve regeneration (Tesser et al., 1986; Glasgow et al., 1994). On the other hand, NF mRNA, protein synthesis, and transport are reduced in mammalian peripheral (Hoffman et al., 1985; Goldstein et al., 1988; Oblinger and Lasek, 1988) and central neurons (Mikucki and Oblinger, 1991; Tetzlaff et al., 1991; Hoffman et al., 1993; McKerracher et al., 1993a) after axotomy. The changes are reversed in peripheral neurons only after regenerating axons reach their targets (Hoffman et al., 1985; Hoffman and Cleveland, 1988; Muma et al., 1990; Wong and Oblinger, $1990 \mathrm{~b}$ ), and they persist if regeneration is prevented (Tetzlaff et al., 1988; Jiang et al., 1994). In mammalian central neurons, which normally do not regenerate, NF message remains permanently depressed (Mikucki and Oblinger, 1991; Tetzlaff et al., 1991). These observations have led to the widespread assumption that NFs play only a passive role in axonal regeneration.

To resolve some of these discrepancies, we have investigated the pattern of NF mRNA expression in axotomized lamprey reticulospinal neurons. These neurons express high levels of the single NF protein NF-180 (Pleasure et al., 1989; Swain et al., 1994;
This research was supported by National Institutes of Health Grant NS14837. A.J.J. was supported as a National Institutes of Health Medical Scientist Training Program Trainee, Grant 5-T32-GM07170.

Correspondence should be addressed to Dr. Michael E. Selzer, Department of Neurology, University of Pennsylvania Medical Center, Philadelphia, PA 19104-4283.

Dr. Jacob's current address: Department of Neurosurgery, University of California Medical Center, San Francisco, CA 94143.

Copyright (C) 1997 Society for Neuroscience $0270-6474 / 97 / 175206-15 \$ 05.00 / 0$ 


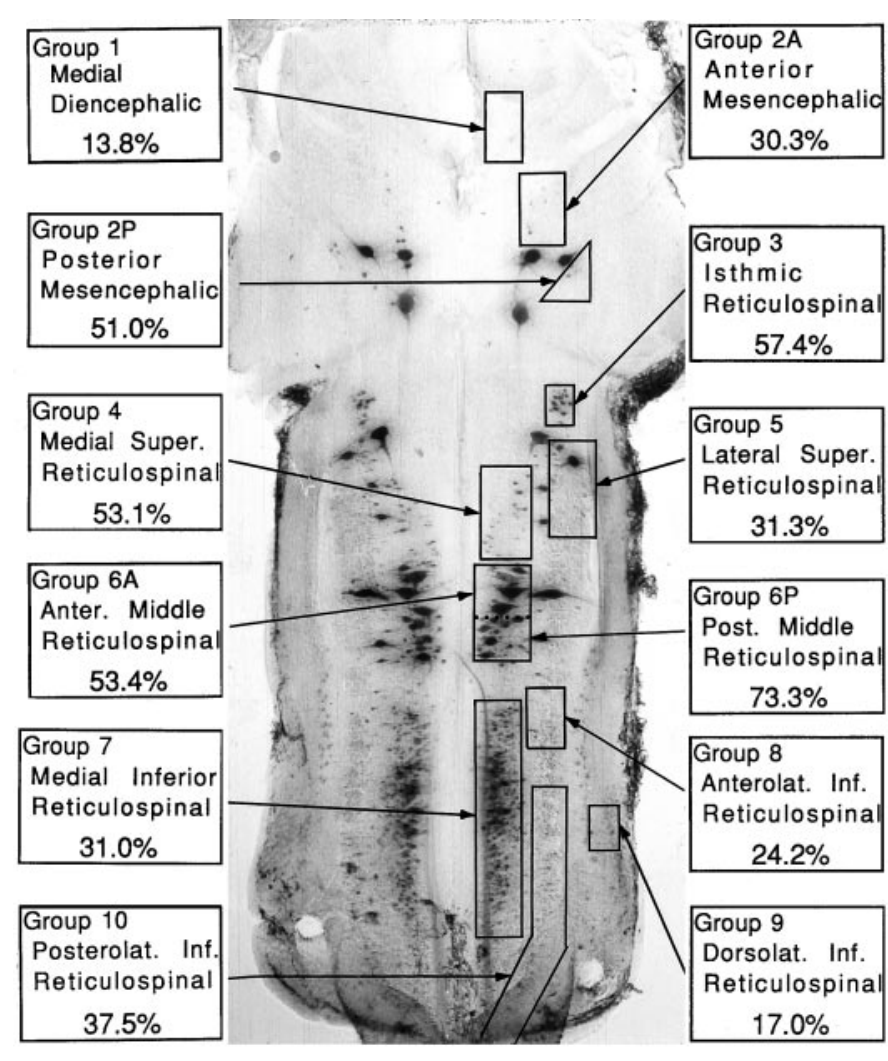

Figure 1. Heterogeneity in regenerative ability among cytoarchitectonic groups of spinal projecting neurons in the lamprey brain. The spinalprojecting neurons in the brain of a large larval sea lamprey were labeled by retrograde transport of HRP and divided into cytoarchitectonic groups according to the nomenclature in Swain et al. (1993). For each group, the probability of regeneration was determined by injecting HRP caudal to the site of transection performed 65-95 d earlier, as described in Materials and Methods. In addition to the nuclear groups of small neurons, several giant reticulospinal neurons are seen. These are the Müller and Mauthner neurons described in subsequent figures.

Jacobs et al., 1995b). In the lamprey, NF production is regulated by a single gene (Jacobs et al., 1995a), and the capacity of individual neurons to regenerate is variable (Swain, 1989; Davis and McClelland, 1994a,b). Thus NF expression can be compared in regenerating and nonregenerating neurons growing through the same CNS milieu.

\section{MATERIALS AND METHODS}

Spinal cord transection. Wild-type larval lampreys, Petromyzon marinus, $10-14 \mathrm{~cm}$ in length, obtained from the Connecticut River (Massachusetts) or from streams feeding Lake Champlain (Vermont), were maintained in fresh water tanks at $16^{\circ} \mathrm{C}$ until the day of surgery. Animals were anesthetized by immersion in $0.1 \%$ tricaine methane sulfonate, and the spinal cord was exposed from the dorsal midline at the level of the fifth gill. Transection of the flat, ribbon-like lamprey spinal cord was performed with Castroviejo scissors. Completeness of full transections was confirmed by retraction and visual inspection of the cut ends. Hemisections of the spinal cord were performed by first making a $0.5 \mathrm{~mm}$ longitudinal incision along and through the central canal and then using Castroviejo scissors to transect the right hemicord. Retraction and visual inspection confirmed completeness and accuracy of the hemisection. Animals in which hemisection was judged to be incomplete or to extend far beyond the midline at the time of surgery were discarded, but slight overhemisection was accepted and even presumed. To block regeneration of transected reticulospinal axons, $5 \mathrm{~mm}$ of spinal cord caudal to the transection was excised, leaving a large gap through which transected axons were incapable of regenerating (Mackler et al., 1986). Successful regeneration of reticulospinal axons requires the presence of glial elements in the lesion site (Lurie and Selzer, 1991b). Transected lampreys recovered in fresh water tanks at room temperature until brainstems were removed for in situ hybridization or for retrograde labeling of regenerated neurons. Animals with distal spinal cordectomy did not regain voluntary movement of body segments below the lesion site up to 1 year after surgery.

Retrograde labeling of regenerated reticulospinal neurons. The probability of regeneration of axons belonging to identified reticulospinal neurons and to neurons of various spinal-projecting cytoarchitectonic groups (Swain et al., 1993) was determined by retrograde transport of horseradish peroxidase (HRP) (Swain, 1989; Davis and McClellan, 1993, 1994b) in 27 completely transected animals that were allowed to recover for 65-95 d. Regeneration of reticulospinal axons after spinal hemisection was determined at 10 weeks after lesion by retrograde labeling in five additional animals. To determine the minimum distance required to guarantee that injected HRP would not spuriously label unregenerated neurons by extracellular diffusion through the spinal cord, a series of control experiments was performed on 40 larval lampreys that had received complete spinal cord transections at the level of the fifth gill. In these experiments, if HRP was applied after the formation of the glial/ependymal scar ( $6 \mathrm{~d}$ or more) but before any reticulospinal axons have regenerated ( $21 \mathrm{~d}$ or less), no reticulospinal neurons were labeled when the HRP was applied at least $2.5 \mathrm{~mm}$ distal to the original transection. Therefore, for the evaluation of regeneration in the present experiments, animals were anesthetized by immersion in $0.1 \%$ tricaine methanesulfonate, and a pledget of Gelfoam soaked in $40 \%$ HRP was placed at the site of a complete spinal transection $5 \mathrm{~mm}$ caudal to the original lesion (transection or hemisection). This labeled reticulospinal neurons whose axons regenerated to at least $2.5 \mathrm{~mm}$ caudal to the initial lesion site and guaranteed that neurons whose axons failed to regenerate were not labeled. The incision was closed with two to three sutures, and the animals were returned to fresh water at room temperature for 7-10 d.

Table 1. Probability of axonal regeneration for spinal-projecting neurons

\begin{tabular}{|c|c|c|c|c|c|c|c|c|c|c|c|c|}
\hline & Group 1 & $2 \mathrm{~A}$ & $2 B$ & 3 & 4 & 5 & $6 \mathrm{~A}$ & $6 \mathrm{P}$ & 7 & 8 & 9 & 10 \\
\hline $\begin{array}{l}\text { CTRLS } \\
\quad \pm \text { SE } \\
\quad(n=8)\end{array}$ & $13.3 \pm 1.2$ & $17.5 \pm 1.3$ & $7.3 \pm 0.7$ & $20.6 \pm 2.0$ & $28.6 \pm 2.4$ & $37.5 \pm 2.7$ & $14.0 \pm 2.5$ & $28.3 \pm 2.1$ & $399.5 \pm 24.3$ & $17.0 \pm 1.4$ & $25.1 \pm 2.9$ & $87.7 \pm 7.6$ \\
\hline $\begin{array}{l}\text { TRANS } \\
\quad \pm \text { SE } \\
\quad(n=27)\end{array}$ & $1.8 \pm 0.3$ & $5.3 \pm 0.6$ & $3.7 \pm 0.3$ & $11.9 \pm 0.9$ & $15.2 \pm 1.1$ & $11.7 \pm 1.2$ & $7.5 \pm 0.6$ & $20.7 \pm 1.3$ & $123.8 \pm 7.9$ & $4.1 \pm 0.4$ & $4.3 \pm 0.8$ & $32.9 \pm 3.1$ \\
\hline $\begin{array}{c}\% \text { REG } \\
\pm \mathrm{SE}\end{array}$ & $13.8 \pm 2.1$ & $30.3 \pm 3.6$ & $51.0 \pm 4.7$ & $57.4 \pm 4.1$ & $53.1 \pm 3.7$ & $31.3 \pm 3.2$ & $53.4 \pm 4.4$ & $73.3 \pm 4.5$ & $31.0 \pm 2.0$ & $24.2 \pm 2.4$ & $17.0 \pm 3.0$ & $37.5 \pm 3.5$ \\
\hline
\end{tabular}

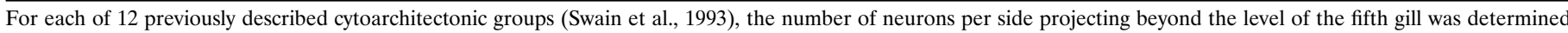

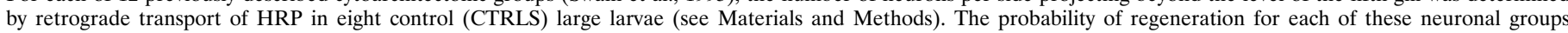

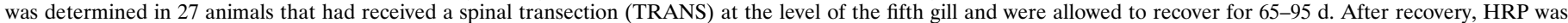

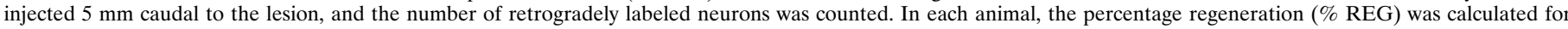

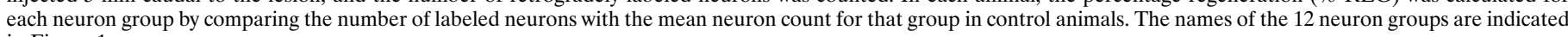
in Figure 1. 


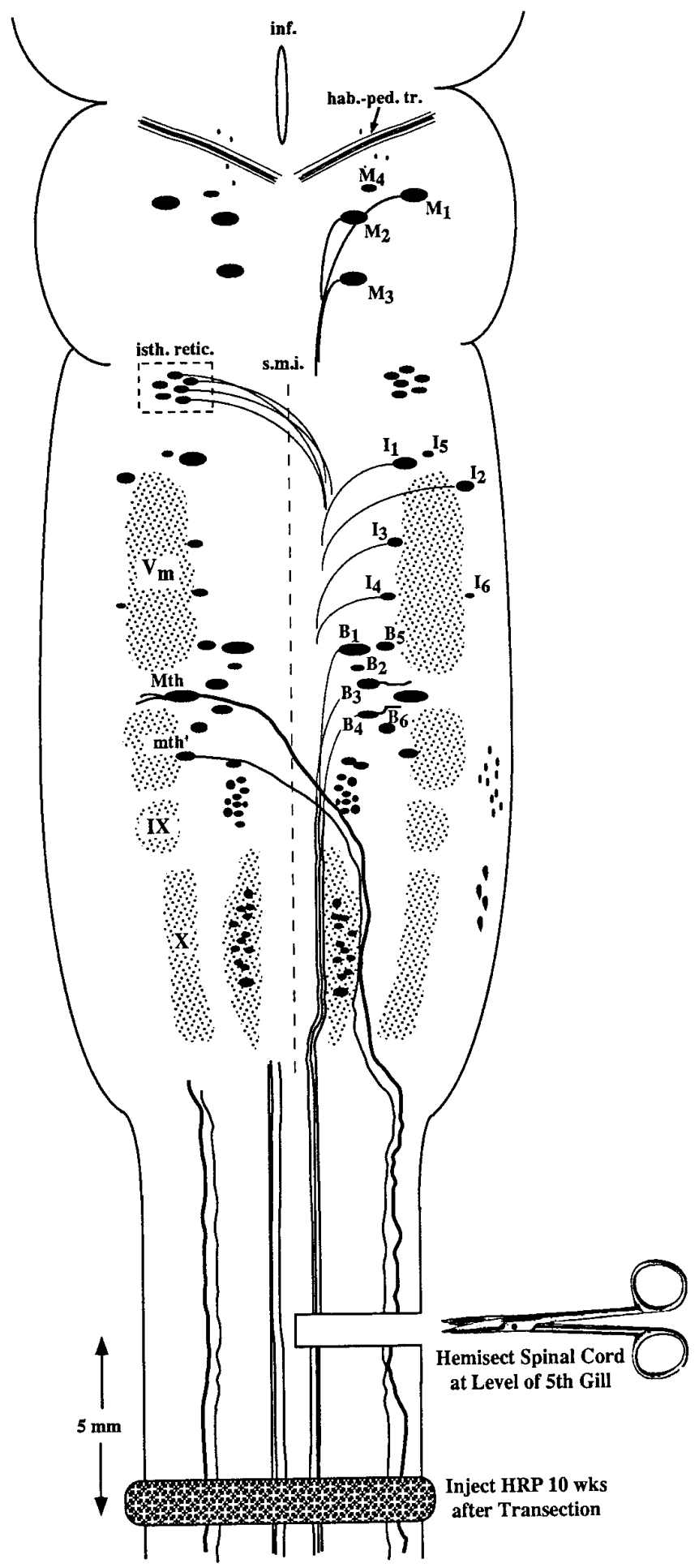

Figure 2. Experimental diagram of hemisection protocol. Anatomical landmarks: the brain of the large larval lamprey is diagrammed to illustrate the locations of large individually identified spinal-projecting neurons together with their mode of axonal projection (crossed or uncrossed). The left-hand members of these paired neurons are labeled according to the nomenclature of Rovainen (1967) as modified by Swain et al. (1993). $M$, Mesencephalic; $I$, isthmic; $B$, bulbar; $M t h$, Mauthner cell; $m t h^{\prime}$, auxiliary Mauthner cell; hab.-ped. tr., habenulopeduncular tract; inf., infundibulum; isth. retic., isthmic (anterior rhombencephalic) reticulospinal nucleus; s.m.i., sulcus medianus inferior; $V_{m}$, trigeminal motor nucleus; $I X$, glossopharyngeal motor nucleus; $X$, vagal motor nucleus. The unlabeled cell mass lateral to $m t h^{\prime}$ and lying between $V$ and $I X$ is the facial motor nucleus. Experiment: the spinal cord was hemisected on the right side at
Animals were subsequently reanesthetized, and the CNS was removed as described for in situ hybridization. Retrograde transport of HRP into brainstem neurons was detected by incubation in Hanker-Yates reagent, followed by dehydration in serial ethanols, clearing in methyl salicylate, and whole-mounting under DPX (Fluka, Buchs, Switzerland). For each cytoarchitectonic group, the number of retrogradely labeled neurons in previously transected animals was compared with the mean number of neurons labeled by injection of HRP at the same spinal cord level (i.e., 5 $\mathrm{mm}$ caudal to the fifth gill) in eight previously uninjured control animals (Swain et al., 1993) to calculate a percentage regeneration.

In situ hybridization of digoxigenin-labeled riboprobes. Hybridization of digoxigenin-labeled riboprobes to whole-mounted lamprey brainstem was performed using the technique similar to that of Swain et al. (1994). Tissue was fixed in $2 \%$ paraformaldehyde overnight, washed three times in PBS, and stored in $70 \%$ ethanol at $4^{\circ} \mathrm{C}$. Digoxigenin-labeled cRNA riboprobes were constructed from clone LIF13 that encompasses the long C-terminal sidearm of NF-180. In vitro transcription (kit, Stratagene, La Jolla, CA) was performed with a 35:65 ratio of digoxigenin-11-UTP/ unlabeled UTP (Boehringer Mannheim, Indianapolis, IN) followed by incubation with sodium carbonate $\left(0.1 \mathrm{M} \mathrm{Na}_{2} \mathrm{CO}_{3}, 65^{\circ} \mathrm{C}, 85 \mathrm{~min}\right)$ to fragmented cRNA transcripts into approximately 100 nucleotide polymers that were subsequently precipitated with ethanol.

Whole-mounted brainstem preparations were washed in PTw $(0.1 \%$ Tween 20 in PBS) and prehybridized at $55^{\circ} \mathrm{C}$ in hybridization solution (50\% deionized formamide; $5 \times \mathrm{SSC} ; 100 \mathrm{mg} / \mathrm{ml}$ Torula yeast RNA; 100 $\mathrm{mg} / \mathrm{ml}$ wheat germ tRNA; $50 \mathrm{mg} / \mathrm{ml}$ heparin; $0.1 \%$ Tween 20 ), followed by hybridization overnight at $55^{\circ} \mathrm{C}$ in the same solution plus $400 \mathrm{ng} / \mathrm{ml}$ digoxigenin-labeled cRNA. The next day, specimens were washed in hybridization solution at $60^{\circ} \mathrm{C}$ followed by room temperature washes in PTw and PBT (0.1\% BSA, $0.2 \%$ Triton X-100 in PBS). Alkaline phosphatase-conjugated anti-digoxigenin Fab $(0.75 \mathrm{U} / \mathrm{ml}$; Boehringer Mannheim, Indianapolis, IN) was diluted 1:1000 and applied to tissue overnight at $4^{\circ} \mathrm{C}$. Tissue was washed sequentially in PBT and SMT (100 $\mathrm{mm} \mathrm{NaCl}, 50 \mathrm{~mm} \mathrm{MgCl}, 100 \mathrm{~mm}$ Tris, $\mathrm{pH} \mathrm{9.5,} \mathrm{0.1 \%} \mathrm{Tween} \mathrm{20).}$ Chromogenic reaction was performed in ice-cold SMT containing 175 $\mathrm{mg} / \mathrm{ml}$ 5-bromo-4-chloro-3-indolyl-phosphate and $350 \mathrm{mg} / \mathrm{ml}$ 4-nitro blue tetrazolium chloride for $30 \mathrm{~min}$ on ice in the dark, followed by two PBS washes, dehydration in serial ethanols, clearing in methyl salicylate, and mounting under DPX.

Semi-quantitative estimation of message level. The level of expression of NF-180 message in individual identified neurons was estimated in brainstem whole mounts after hybridization to digoxigenin-labeled NF-180 ribonucleotide probes, as described previously (Jacobs et al., 1995b). Although less quantitative, this technique was preferred to radioisotopic hybridization for two reasons: (1) identification of individual Müller cells would be difficult in paraffin sections, whereas it is straightforward in whole mounts; and (2) the large size of the Müller and Mauthner cells would require that grains be counted in autoradiographs from as many as 10 serial paraffin sections for each cell. Therefore, a semiquantitative integer scale from 0 to 4 was used to grade the intensity of labeling for NF-180 message in individual giant reticulospinal neurons. The criteria for each score was as follows: 0, no label observed in intact neurons identified by light and differential interference contrast microscopy at $40 \times$ magnification; 1 , faint staining limited to the perimeter of the perikaryon; 2, faint staining throughout the cytoplasm; 3 , intense staining throughout the cytoplasm but not sufficiently dark to obscure the nucleus; 4 , staining sufficiently dark to completely obscure the nucleus. To confirm the reproducibility of this scale, scoring was performed independently by two observers, one of whom was blind to the experimental manipulation of the animals. There was a 95\% concordance between the two scorers; $89 \%$ percent of the discrepancies were a difference of one grade level, and none were more than two levels.

$\leftarrow$

the level of the fifth gill, producing axotomy of the Müller cells and other reticulospinal neurons with uncrossed axons on the right side of the brain, and the Mauthner cell, auxiliary Mauthner cell, isthmic reticulospinal neurons, and other neurons with decussated axons on the left side of the brain. Animals were permitted to recover for 10 weeks, at which time a complete spinal cord transection was performed $5 \mathrm{~mm}$ caudal to the original hemisection, and HRP was applied to the cut ends of spinal cord. Previously unaxotomized neurons and neurons whose axons had regenerated were labeled by retrograde transport. Previously axotomized neurons whose axons had not regenerated at least $2.5 \mathrm{~mm}$ (see Materials and Methods) were not labeled. 


\begin{tabular}{|c|c|c|c|c|c|c|c|c|c|c|}
\hline Cell & $\mathrm{M}_{1}$ & $\mathrm{M}_{2}$ & $\mathrm{M}_{3}$ & $\mathrm{M}_{4}$ & $\mathrm{I}_{1}$ & $\mathrm{I}_{2}$ & $\mathrm{I}_{3}$ & $\mathrm{I}_{4}$ & $\mathrm{I}_{5}$ & $\mathrm{I}_{6}$ \\
\hline$\%$ Regen & 48.2 & 13.0 & 13.0 & 63.0 & 3.7 & 37.0 & 70.4 & 59.3 & 68.5 & 57.4 \\
\hline Cell & $\mathrm{B}_{1}$ & $\mathrm{~B}_{2}$ & $\mathrm{~B}_{3}$ & $\mathrm{~B}_{4}$ & $\mathrm{~B}_{5}$ & $\mathrm{~B}_{6}$ & Mth & mth' & & \\
\hline$\%$ Regen & 18.5 & 46.3 & 5.6 & 11.1 & 70.4 & 61.1 & 7.4 & 68.5 & & \\
\hline
\end{tabular}

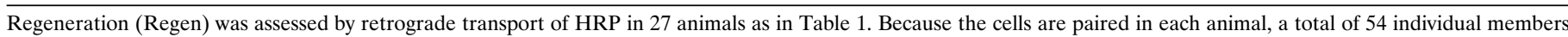
of each cell type were counted. Cell nomenclature is that of Rovainen (1967) as extended by Swain et al. (1993). Mth, Mauthner cell; mth', auxilliary Mauthner cell.

\begin{abstract}
Quantification of NF-180 protein content. Complete spinal cord transections were performed as above. Five lampreys from each of 10 time points from 0 (control) to 20 weeks after transection and five sham-operated controls each at 1 and 2 weeks were reanesthetized in tricaine methanesulfonate; brains were resected under lamprey Ringer's solution. Specimens were immediately placed in sample buffer ( $1 \%$ sucrose, $9 \mathrm{~mm}$ Tris, pH 6.8, 1 mM EDTA, 0.006\% dithiothreitol, 0.01\% SDS) and homogenized. Homogenate was denatured at $100^{\circ} \mathrm{C}$, centrifuged for $5 \mathrm{~min}$ at $16,000 \times g$, and stored at $-80^{\circ} \mathrm{C}$. Protein concentration of thawed samples was determined by the Bradford protein assay (Bradford, 1976) and standardized to known concentrations of bovine serum albumin. Sixty micrograms of total brain homogenate were separated by electrophoresis through $7.5 \%$ SDS polyacrylamide (Lee et al., 1986) and subsequently stained by $0.1 \%$ Coomassie blue R250 in water/methanol/glacial acetic acid (5:5:2) and destained in $12.5 \%$ methanol and $10 \%$ glacial acetic acid. Coomassie-stained gels were scanned by a Hewlett Packard ScanJet Plus with Adobe Photoshop software on a Macintosh IIfx computer. Staining density of NF-180 bands was determined with Image 1.52 software (National Institutes of Health, Bethesda, MD), and protein content was determined by reference to calibrated bands of a high molecular weight standard. This technique has proven comparable to laser scanning densitometry when appropriate adjustments are made for nonlinearities (Kendrick et al., 1994). NF-180 has previously been shown to be the only CNS protein migrating at $180 \mathrm{kDa}$ in the lamprey (Pleasure et al., 1989). Density of the NF-180 band was normalized to a $100 \mathrm{kDa}$ protein band that remained constant throughout the period of regeneration.
\end{abstract}

\section{RESULTS}

\section{Heterogeneity of CNS axon regeneration}

Reticulospinal axons of larval and adult lampreys regenerate selectively in their correct directions across complete transections of the spinal cord (Yin et al., 1984; Mackler et al., 1986; Lurie and Selzer, 1991a). By 10 weeks after spinal transection, larval lampreys recover behavioral functions (Rovainen, 1976; Selzer, 1978) that are mediated by the formation of synapses with appropriate neurons distal to the site of injury (Mackler and Selzer, 1987). Spinal-projecting neurons of the lamprey have a complex architecture, with 36 large identified reticulospinal neurons (including seven pairs of giant Müller cells and a pair of Mauthner neurons) and several nuclear groups that contain variable numbers of smaller neurons (Swain et al., 1993). Previous studies have suggested heterogeneity in the ability of individual identified reticulospinal neurons and neuronal groups to regenerate across a complete spinal cord transection (Swain, 1989; Davis and McClelland, 1994b). This was confirmed in 27 large larval lampreys that were allowed to recover for 65-95 d, encompassing the survival times used in the in situ hybridizations. Regeneration rates exceeding 50\% were observed among neurons of the middle reticulospinal, isthmic reticulospinal, medial superior reticulospinal, and posterior mesencephalic groups (Fig. 1, Table 1). On the other hand, regeneration rates of $<20 \%$ were observed among neurons of the medial diencephalic and dorsolateral inferior reticulospinal groups.

Heterogeneity was also found in the regeneration of axons belonging to the individually identified giant reticulospinal neurons (Figs. 1, 2), including the Müller and Mauthner cells (Rovainen, 1967; Swain et al., 1993). Thus regeneration rates above $50 \%$ were observed for the $\mathrm{B}_{5}, \mathrm{~B}_{6}, \mathrm{I}_{3-6}, \mathrm{M}_{4}$, and auxiliary Mauthner cells, whereas regeneration rates of $<20 \%$ were observed for the $\mathrm{B}_{3}, \mathrm{~B}_{4}, \mathrm{I}_{1}, \mathrm{M}_{2}, \mathrm{M}_{3}$, and Mauthner cells (Table 2).

The present study used spinal hemisections so that NF-180 expression in axotomized giant reticulospinal neurons could be compared with that in their contralateral unaxotomized sister cells. Therefore, heterogeneity in the regenerative capacities of these large identified neurons was confirmed in five spinal hemisected animals by caudal application of HRP 10 weeks after lesioning (diagrammed in Fig. 2). As in the completely transected animals, spinal-projecting neurons exhibited a variable capacity for axonal regrowth (Fig. $3 A$ ). Moreover, the neurons that regenerated most successfully in these hemisected preparations tended to be the same as those that had the greatest probability of regeneration in the larger sample of completely transected animals. Thus in hemisected animals, at least $75 \%$ of axotomized giant reticulospinal neurons $B_{2}, B_{5}, B_{6}, I_{3}, I_{4}, I_{5}$, and $M_{4}$ extended neurites caudal to the lesion, whereas axons of the Mauthner and $\mathrm{I}_{1}$ neurons were never detected beyond the lesion (Fig. 3B).

Neither distance of axotomy from the cell body nor location of cell body within the brainstem seemed to correlate with regenerative success. Cell $\mathrm{M}_{4}$, whose perikaryon is the most rostral of the identified reticulospinal neurons, readily extended a nascent axon past the lesion site (100\% regeneration), whereas adjacent neurons $\mathrm{M}_{1-3}$ were much less successful (Table 2, Fig. $3 B$ ). The large identified bulbar neurons were similarly heterogeneous in their capacity to regenerate axons. Neuron $\mathrm{B}_{2}$ regrew its axon in $46 \%$ of transected larvae and $100 \%$ of hemisected larvae, whereas its neighbors $B_{1}$ and $B_{3}$ successfully extended neurites only $6-19 \%$ of the time in transected larvae and $40 \%$ of the time in hemisected animals, despite similarities in cell size and location. Among the smaller neurons of the reticulospinal nuclei, the posterior mesencephalic group regenerated $51 \%$ of the time in transected animals (Fig. 1) and $67 \%$ of the time in the hemisected animals (Fig. 3B), whereas the regeneration probabilities for the similarly sized neurons of the adjacent anterior mesencephalic group were only $30 \%$ and $24 \%$ in transected and hemisected animals, respectively. The small isthmic (anterior rhombencephalic) reticulospinal group neurons regenerated $\sim 60 \%$ of the time (Figs. 1, 3B), whereas the similarly small neurons of the adjacent lateral superior reticulospinal group regenerated only half as often. Regeneration in other groups of small reticulospinal neurons was not quantified in hemisected animals because the spinal trajectories of their axons are not known, and it was not possible to be certain that the hemisection resulted in unilateral axotomy. Thus retrograde labeling might underestimate the population of neurons in the contralateral "control" side of the brain; however, qualitatively, the pattern of regenerative capabilities for these neuron groups was consistent with that in transected animals. Neuron groups that regenerated well after complete spinal transection also regenerated well after hemisection and vice versa. This is 


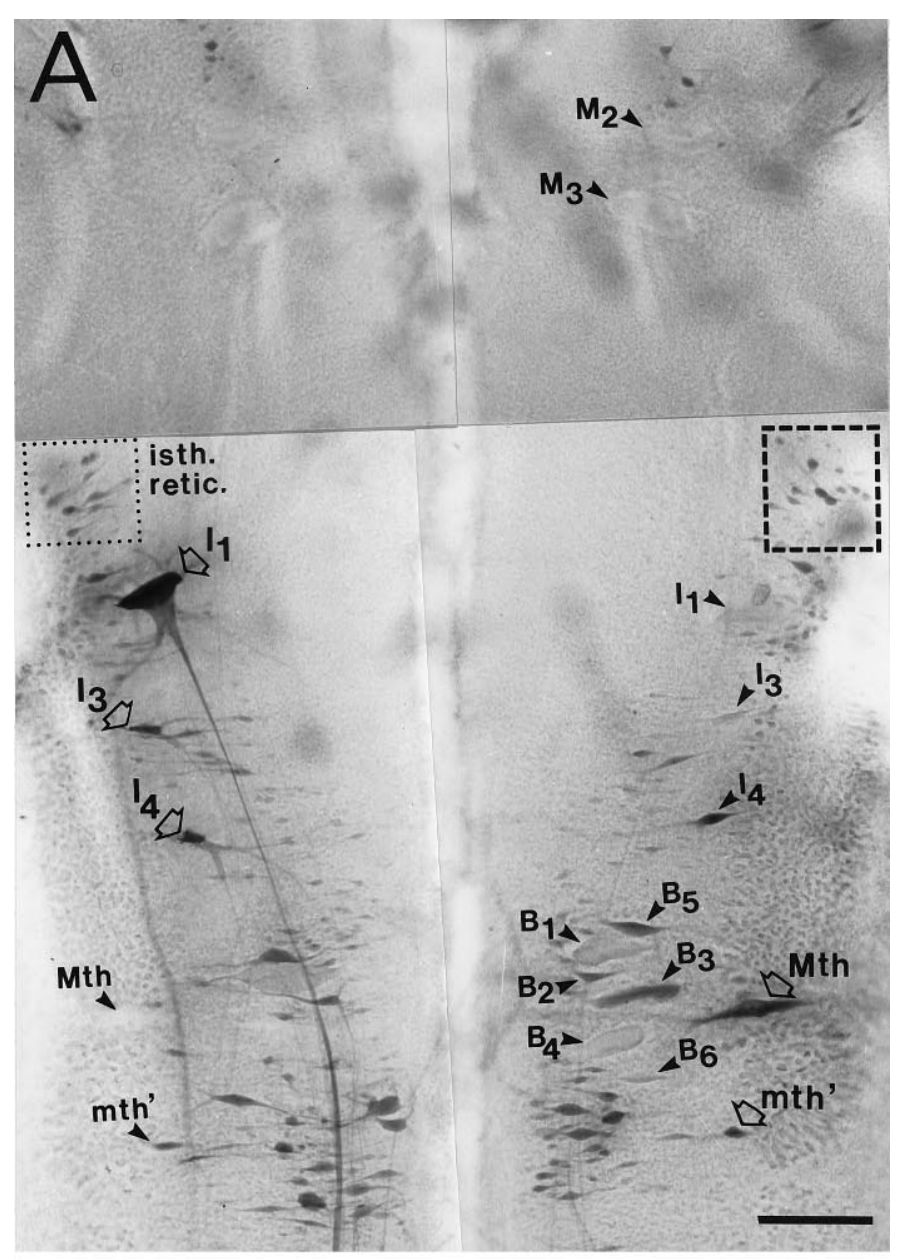

B

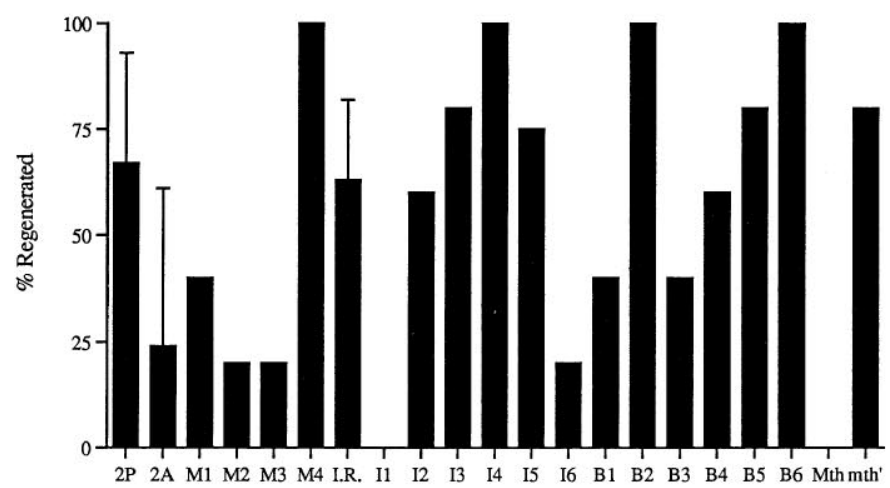

Neuron

Figure 3. Heterogeneity in regeneration of lamprey reticulospinal axons after spinal hemisection. $A$, Retrograde HRP labeling of regenerated reticulospinal neurons 10 weeks after right-sided spinal hemisection. Neurons whose axons were cut by the hemisection are indicated by arrowheads, whereas neurons whose axons would not have been cut by the hemisection are indicated by open arrows. Neurons whose axons regenerated are stained darkly, as are contralateral uninjured neurons. The pale unlabeled profiles of several nonregenerating giant reticulospinal neurons are also indicated with arrowheads (e.g., $M_{2}, M_{3}$, and $I_{1}$ on the right, and $M t h$ on the left). Numerous regenerated neurons of the isthmic reticulospinal group (isth. retic., dotted box) are stained comparably to their uninjured counterparts (dashed box). Note that axons of isthmic reticulospinal neurons and of the Mauthner $(M t h)$ and auxiliary Mauthner $\left(m t h^{\prime}\right)$ cells decussate before entering the spinal cord. Because of the close proximity of mesen- expected because in the lamprey, axons in a hemisected cord regenerate preferentially through the hemisection scar rather than around it (Lurie and Selzer, 1991c). Thus the presence of untransected contralateral spinal cord would not significantly modify the extracellular environment through which axons regenerated.

\section{NF-180 mRNA expression in axotomized central neurons}

NF-180 hybridizes strongly to reticulospinal neurons and motor neurons of cranial nerve nuclei (Swain et al., 1994; Jacobs et al., 1995a,b). In the present study, each of the identified reticulospinal neurons expressed abundant NF-180 mRNA, as demonstrated by strong labeling of these cells in brainstems of large larvae (Fig. $4 A$ ). Changes in NF-180 mRNA expression were analyzed at 1, 2, 4,7 , and 10 weeks after either spinal cord hemisection or complete spinal transection. A total of 33 animals met criteria for adequacy of hemisection. Of these, at least four survived and were studied at each time point. Axotomized neurons in these preparations were compared with their contralateral unaxotomized sister cells and with the corresponding cells in five untransected controls. Because the lamprey expresses a single NF subunit that is homologous to all three mammalian NFs (Jacobs et al., 1995a), in situ levels of NF-180 mRNA should account for all NF synthesized in these neurons. Examples of NF-180 in situ hybridization to control and to larval brainstems 4 weeks after transection are shown in Figure 4, $A$ and $B$, respectively. Axotomized reticulospinal neurons were often swollen and chromatolytic (NF-180 mRNA dispersed to the cell margins) and stained less strongly than unaxotomized contralateral neurons early after transection. At 1 week after axotomy, most identified reticulospinal neurons showed morphological changes of injury. Cell bodies lost their typical round, plump appearance and became contracted, mottled, and irregularly shaped. Labeling for NF-180 mRNA, which was homogeneous and mostly restricted to the perikaryon of intact neurons, became stippled and peripherally marginated and frequently extended into proximal dendrites and axons 1 week after axotomy. Hybridization intensity was reduced at 1 week in many isthmic (e.g., $\mathrm{I}_{1-4}$ ) and bulbar (e.g., $\mathrm{B}_{1-4}, \mathrm{~B}_{6}$, Mauthner) reticulospinal neurons (Figs. 5, 6); however, prominent changes in NF-180 levels in spinal-projecting neurons $\mathrm{M}_{1-4}, \mathrm{I}_{5}, \mathrm{~B}_{5}$, and auxiliary Mauthner were delayed until the second week after axotomy. The difference of up to 1 week in the onset of cytoskeletal changes for neighboring rhombencephalic neurons suggests that initiation of cell body response to axotomy was not solely dependent on distance from the lesion.

By 4 weeks after transection, axotomized large reticulospinal neurons were swollen and most had dramatically reduced levels of

cephalic and some bulbar giant reticulospinal axons in the ventromedial spinal cord, contralateral axons were occasionally injured by the hemisection. This probably accounts for the lack of labeling of $\mathrm{M}_{1-3}$ on the left side of the brain. Scale bar, $150 \mu \mathrm{m}$. B, Probability of axonal regeneration by reticulospinal neurons 10 weeks after spinal hemisection. For each identified neuron or neuron group, the percentage of axons that regenerated was determined in five animals by retrograde filling of the cell body with HRP applied caudal to the hemisection as diagrammed in Figure 2. Standard error bars are shown for the three nuclear groups included in this figure $(2 P, 2 A$, and $I . R$. $=$ isthmic reticulospinal or group 3$)$, because these represent several neurons in each brain. These three groups were included because they were considered to have been reliably hemisected, based on control retrograde labeling experiments. It is presumed that their axons do not course near the midline at the level of the hemisection. 

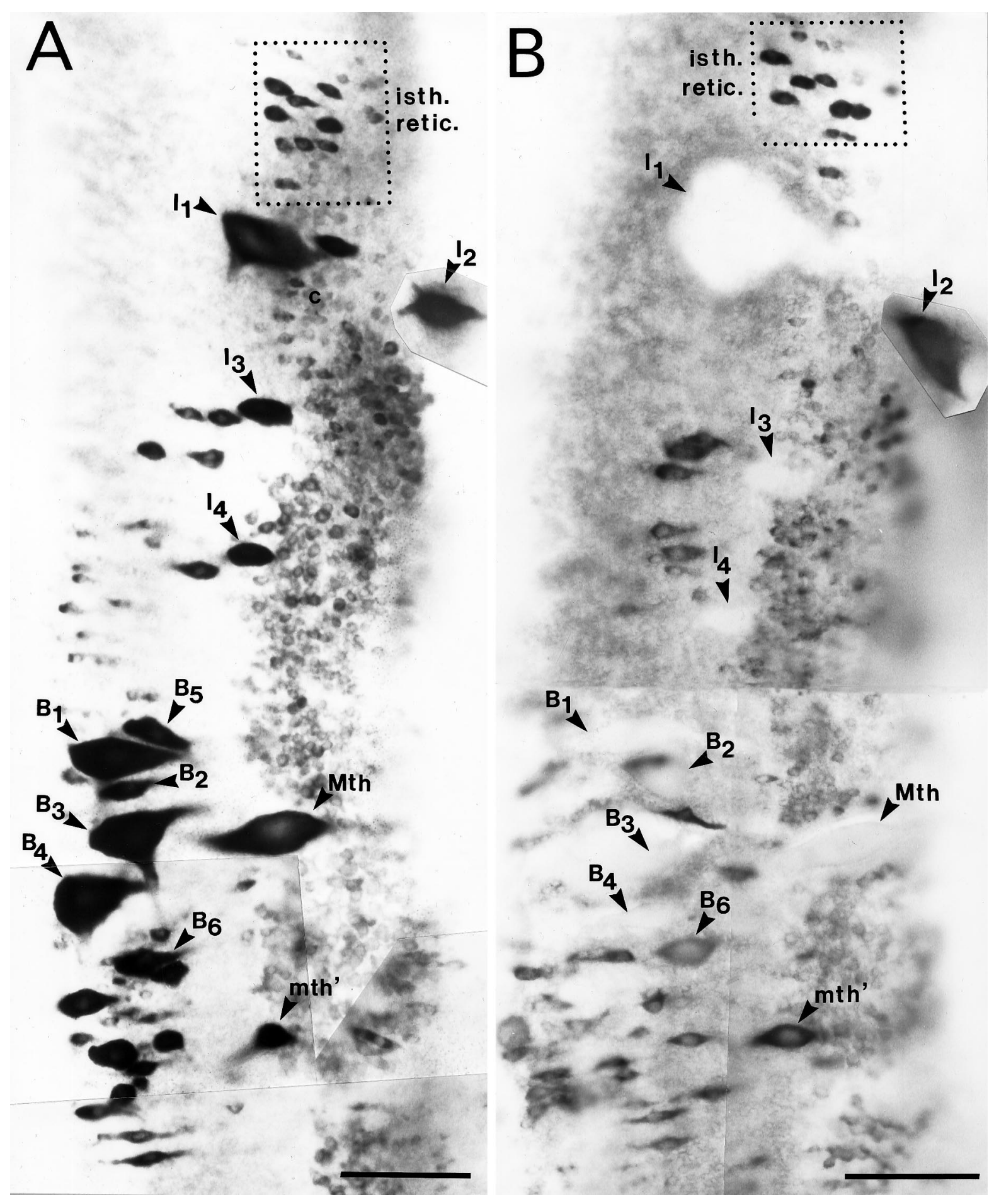

Figure 4. Reduced expression of NF-180 mRNA after axotomy of reticulospinal neurons. $A$, In situ hybridization in whole-mounted control brainstem showing abundant message in all large identified reticulospinal neurons (arrowheads) and neurons of the isthmic reticulospinal cell group (isth. retic.). $B$, Axotomized reticulospinal neurons 4 weeks after spinal cord hemisection. Note that many identified reticulospinal neurons are swollen and have dramatically decreased labeling for NF-180 message compared with untransected counterparts. Axons of the isthmic reticulospinal group (isth. retic.) and Mauthner $(M t h)$ and auxiliary Mauthner $\left(m t h^{\prime}\right)$ cells project to the contralateral hemicord and were therefore not transected. Note that expression was nevertheless reduced in the untransected Mauthner cell (see Fig. 7). Scale bar, $100 \mu \mathrm{m}$.

NF-180 mRNA (Figs. 5, 6). Residual expression, when present, was detected primarily along peripheral margins of the perikaryon. Virtually all identified large reticulospinal neurons had marked reduction in NF message compared with untransected neurons. Neurons of the isthmic reticulospinal group, however, displayed markedly higher levels of NF-180 expression than other transected reticulospinal neurons (Fig. 5A,C,E,G). Many of these neurons were prominently labeled by in situ hybridization, although expression was qualitatively less than in the contralateral group. The depression of NF-180 mRNA levels in 

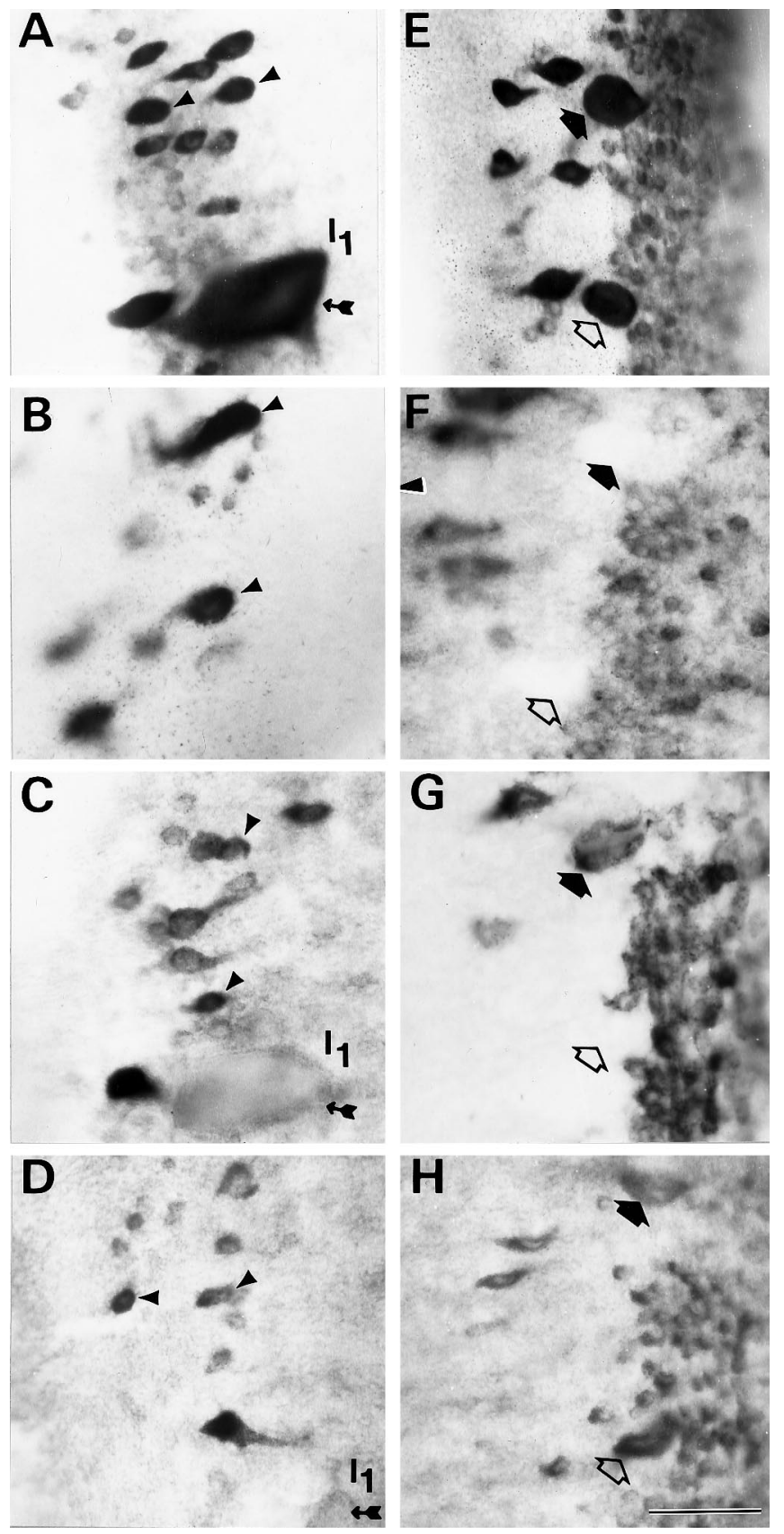

Figure 5. Persistence or recovery of NF-180 mRNA expression selectively in reticulospinal neurons that regenerate beyond the hemisection. The anterior rhombencephalic (isthmic) region in whole-mounted brainstems of control $(A, E)$ and transected animals 1 week $(B, F), 4$ weeks $(C$, $G)$, and 10 weeks $(D, H)$ after spinal hemisection hybridized in situ to a digoxigenin-labeled NF-180 cDNA probe. Note that expression in axotomized isthmic reticulospinal neurons (arrowheads in $A-D$ ) was qualitatively reduced but remained prominent during the period when their axons were regenerating. These neurons show a high probability of axonal regeneration (see Fig. 3B; Table 1). Identified reticulospinal neurons $\mathrm{I}_{3}$ ( filled arrows) and $\mathrm{I}_{4}$ (open arrows) displayed a marked early reduction in NF-180 message level that was reversed by 10 weeks $(E-H)$. These neurons also regenerate axons effectively after transection. Note that the giant reticulospinal neuron $\mathrm{I}_{1}$ (small-tailed arrow in $B-D$ ), which almost never regenerated (Fig. 3B; Table 2), showed persistent downregulation of NF-180 expression. Scale bar, $50 \mu \mathrm{m}$.
A
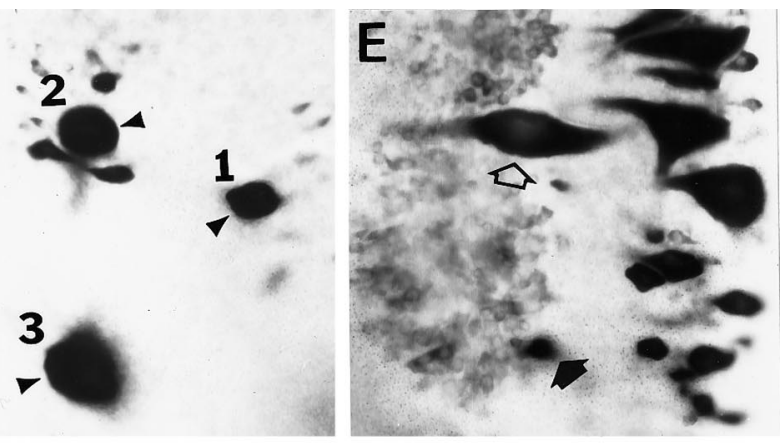

B
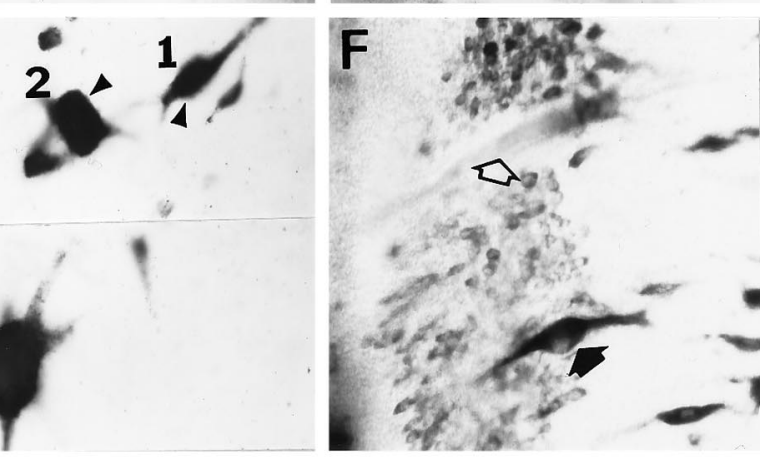

C
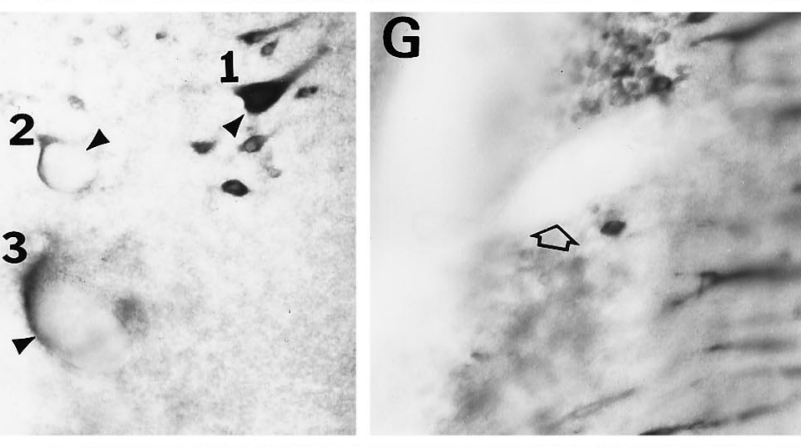

D
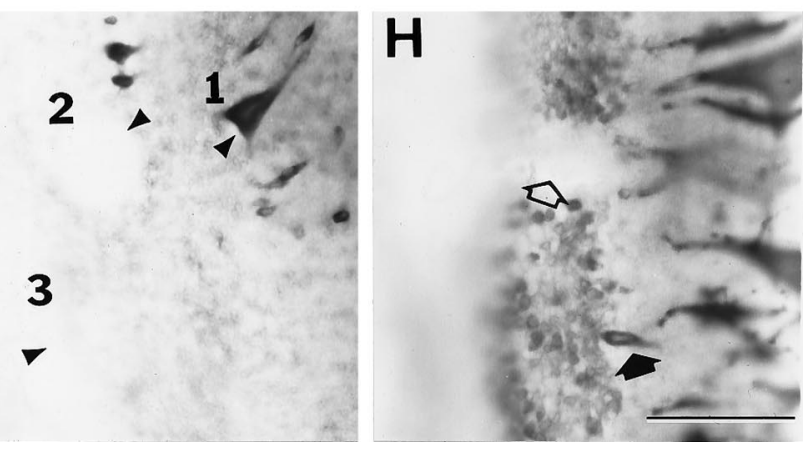

Figure 6. Prolonged depression of NF-180 mRNA expression in poorly regenerating reticulospinal neurons. $A-D$ are high magnification views of the right mesencephalon, in which the giant reticulospinal neurons $\mathrm{M}_{1-3}$ are indicated by arrowheads and the corresponding numeral. $E-F$ show the left middle rhombencephalon in the region of the Mauthner cell, which is indicated by open arrows. In situ hybridization was performed on whole-mounted brainstems of control $(A, E)$ and transected animals 1 week $(B, F), 4$ weeks $(C, G)$, and 10 weeks $(D, H)$ after spinal hemisection. Note that message levels in axotomized reticulospinal neurons $\mathrm{M}_{2}$ and $\mathrm{M}_{3}$, which regenerated poorly (Fig. $3 B$; Table 2 ), were reduced by 4 weeks after axotomy $(C)$ and remained depressed at 10 weeks $(D)$, whereas $M_{1}$, which regenerated more frequently than $M_{2}$ and $M_{3}$, did not show this reduced expression. Axotomized Mauthner neurons (open arrows in $E-H$ ), whose axons rarely regenerated (Fig. 3B; Table 2), exhibited a rapid $(F)$ and sustained depression of NF-180 message $(G, H)$. By contrast, axons of the auxiliary Mauthner neuron ( filled arrows) frequently regenerated (Fig. 3B; Table 2 ). This neuron was slow to lose hybridization labeling $(F)$ and recovered NF-180 expression by 10 weeks after axotomy $(H$; neuron is not visible in panel $G$, presumably because message was below detection level). Scale bar, $100 \mu \mathrm{m}$. 


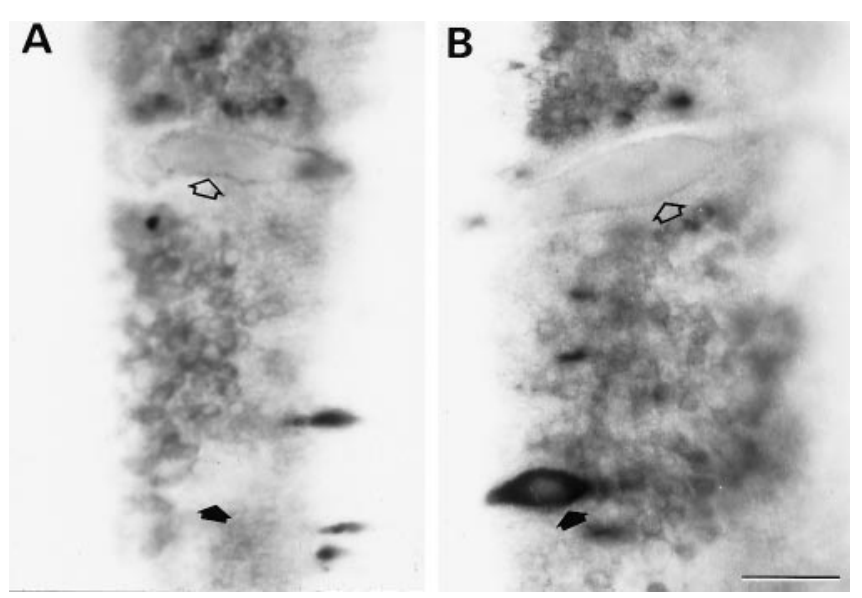

Figure 7. Transneuronal reduction of NF-180 message in uninjured Mauthner neurons at 4 weeks after transection. $A$, Staining for NF-180 message is reduced in axotomized Mauthner (open arrow) and auxiliary Mauthner ( filled arrow) neurons. B, NF-180 message is also reduced in the contralateral, intact Mauthner cell of the same animal (open arrow) but not in the untransected auxiliary Mauthner neuron (filled arrow). Scale bar, $50 \mu \mathrm{m}$.

these cells appeared less than in other axotomized reticulospinal neurons.

Ten weeks after transection, NF-180 mRNA levels remained depressed in most of the large identified reticulospinal neurons, despite dramatic behavioral recovery by this time (Rovainen, 1976; Selzer, 1978; Currie and Ayers, 1983; Cohen et al., 1988). A subset of reticulospinal neurons, however, displayed NF-180 mRNA levels that were significantly higher than levels in the same neurons at 4 weeks. Neurons of the isthmic reticulospinal group were labeled more intensely at 10 weeks than at 4 weeks after axotomy, and several neurons were labeled with intensity similar to untransected controls (Fig. 5E,G). Identified reticulospinal neurons $\mathrm{I}_{3}$ and $\mathrm{I}_{4}$ also recovered much of their NF expression by 10 weeks (Fig. $5 H$ ). A subset of bulbar reticulospinal neurons (i.e., $\mathrm{B}_{2}, \mathrm{~B}_{5}$, and $\mathrm{B}_{6}$ ) displayed a similar recovery in NF expression from a nadir at 4 weeks, whereas expression remained depressed in adjacent neurons (i.e., $\mathrm{B}_{1}$ and $\mathrm{B}_{4}$; data not shown).

\section{Transneuronal downregulation of NF mRNA levels in Mauthner cells}

In hemisected animals, untransected Mauthner neurons frequently displayed reduced levels of NF-180 message with a time course similar to that of the contralateral transected Mauthner cells. Expression in untransected auxiliary Mauthner cells, which also reside in the lateral basal plate, did not change appreciably. Both Mauthner and auxiliary Mauthner axons decussate in the rhombencephalon and descend in the lateral spinal column. Lateral projection at the level of axotomy makes injury to contralateral Mauthner axons unlikely during hemisection, and when HRP was injected at the time of hemisection only one of six ipsilateral Mauthner neurons filled and no auxiliary Mauthner cells were labeled. Yet, 4 weeks after hemisection $80 \%$ of ipsilateral Mauthner cells had no detectable NF-180 mRNA $(n=5)$ (Fig. 7). Expression in untransected ipsilateral auxiliary Mauthner neurons remained prominent, although slightly reduced compared with untransected control animals at 4 weeks. The overall pattern of NF-180 change observed in axotomized Mauthner neurons was paralleled in the uninjured cell, suggesting that signals for regulation of cytoskeletal gene expression may be transmitted from injured to uninjured neurons. Concomitant changes, however, were not observed in other uninjured identified neurons, such as the auxiliary Mauthner or neurons $\mathrm{I}_{3}$ and $\mathrm{I}_{4}$.
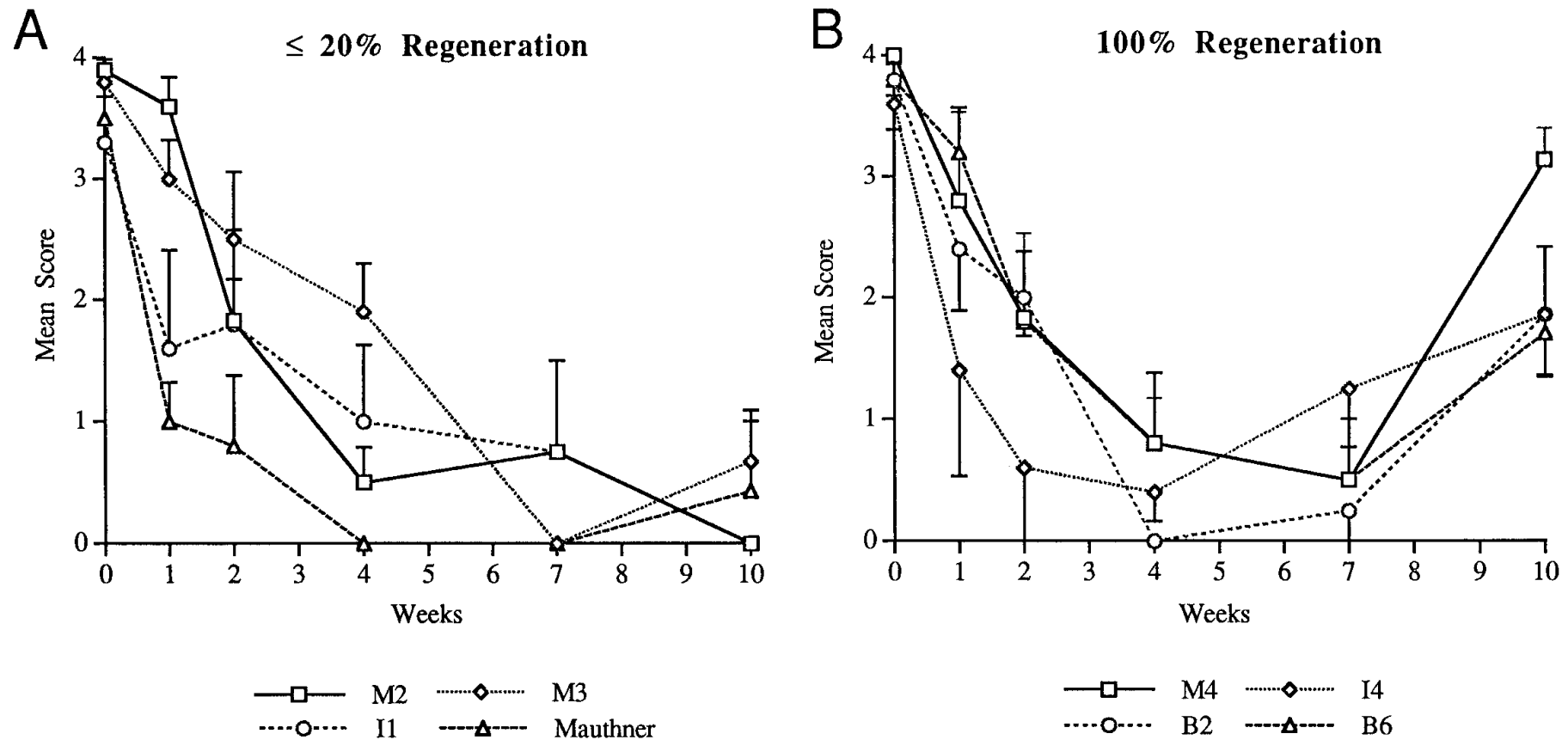

Figure 8. Comparison of the time course of NF-180 expression between poorly regenerating and effectively regenerating neurons. $A$, Time course of mean expression scores in identified reticulospinal neurons that rarely ( $\leq 20 \%$ of cases) regenerated axons across a spinal transection. $B$, Mean expression scores in neurons that always ( $100 \%$ of cases) regenerated axons beyond a hemisection. Scores based on integer scale of staining intensity in individual neurons after hybridization to digoxigenin-labeled cDNA probe (see Materials and Methods). Mean expression scores \pm SEM are shown, four to six animals per time point. Note that expression scores recovered by 10 weeks selectively in neurons that regenerated. 

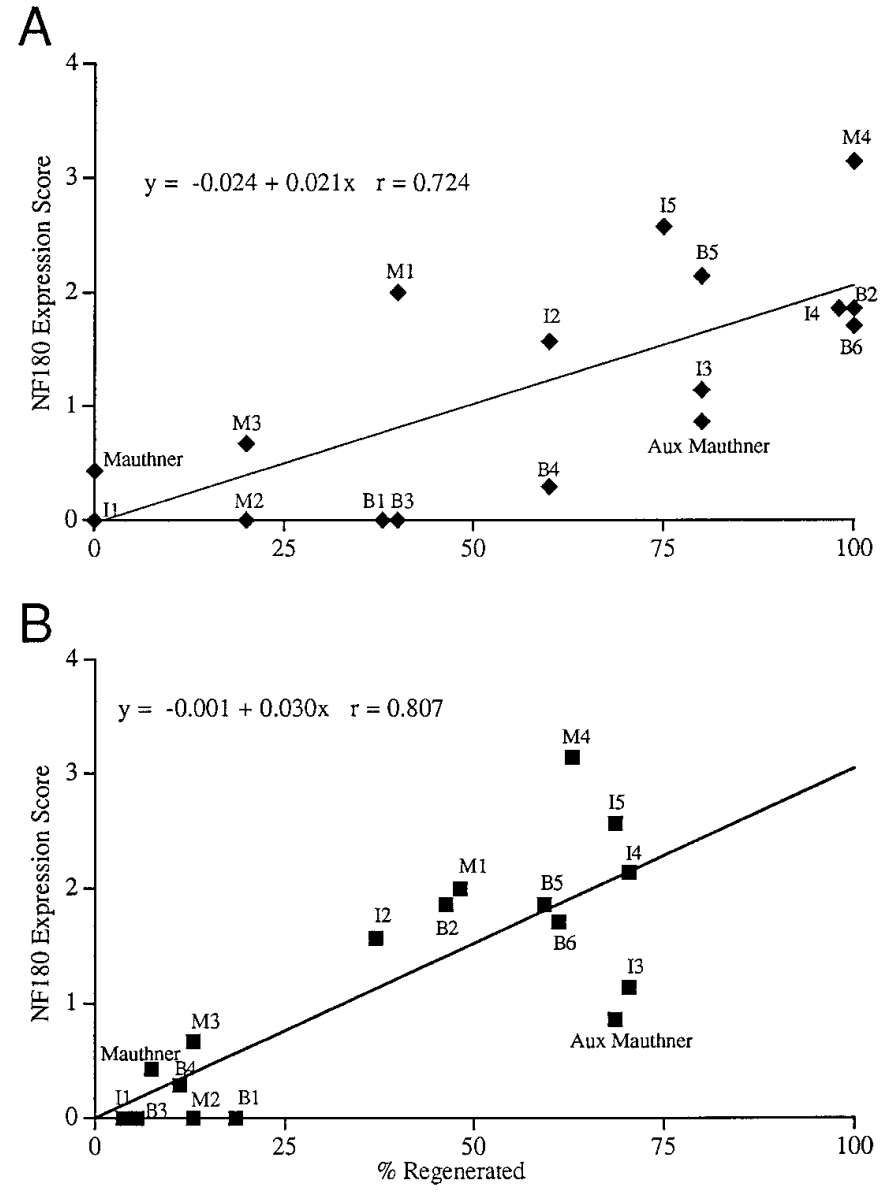

Figure 9. Correlation between NF-180 expression score at 10 weeks and the probability of axonal regeneration in identified reticulospinal neurons. $A$, For each of 17 identified neurons in five hemisected animals, the mean expression score at 10 weeks is plotted against the probability of axonal regeneration across the lesion for that neuron, as measured in five additional hemisected animals permitted to recover 10 weeks $(\bullet)$. The name of each reticulospinal neuron is shown adjacent to its data point. The line represents the best fit linear regression, $r=0.72$. $B$, The same regression but using the probability of regeneration determined in the 27 completely transected animals of Table $2(\mathbf{\square})(r=0.81)$.

\section{Selective recovery of NF expression in regenerating neurons}

Expression of NF-180 message in axotomized reticulospinal neurons reached its lowest point between 4 and 7 weeks after transection, followed by a selective restoration of expression in a subset of regenerating neurons. The magnitude and timing of depression varied with cell type, as did reexpression. To evaluate the hypothesis that reestablishment of NF-180 mRNA occurs selectively in regenerating neurons, NF expression in the identified reticulospinal neurons was correlated with the probability of axonal regeneration by the same neuron. Because of the large size of many of the identified lamprey reticulospinal neurons (50-100 $\mu \mathrm{m}$ diameter), determination of message content by hybridization to tissue sections would require summation of expression in up to 10 serial sections for each neuron. This approach is complicated further by the peripheral margination of message that frequently occurs after axotomy. To circumvent this problem, message content was rated using a semiquantitative integer scale applied to wholemount in situ hybridizations, as described previously (Jacobs et al., 1995b). Each of the large identified reticulospinal neurons was scored for hybridization intensity on a scale from 0 to 4 (see Materials and Methods). Labeling of cranial motor nuclei served as an internal control for each hybridization, and tissue was excluded if adequate signal was not observed.

Overall, the semiquantitative scale followed the subjective impression of message levels after axotomy. Some neurons, such as $\mathrm{I}_{1}$, rapidly and dramatically reduced NF-180 message and had a mean score of 1.6 at 1 week compared with 3.3 in control animals $(n=5)$. Other neurons displayed a less dramatic depression in the first few weeks after transection. The mean score for transected neurons $\mathrm{B}_{4-6}$ was 2.9 at 1 week, down from 3.6 in control animals $(n=5)$. A nadir of NF expression was reached at 4 weeks in most neurons; however, although NF-180 mRNA expression remained low in some transected reticulospinal neurons, other neurons showed recovery of expression toward normal levels by 7-10 weeks (Fig. 8). In several identified neurons of the middle rhombencephalon (e.g., $\mathrm{B}_{2}, \mathrm{~B}_{5}$, and $\mathrm{B}_{6}$ ), levels of NF-180 message at 10 weeks were at least one full score higher than their lowest levels. Recovery of expression was not restricted to a particular brainstem region and was observed in selected reticulospinal neurons throughout the mesencephalon and rhombencephalon. Identified neurons that recovered NF-180 expression in more rostral brainstem regions tended to be smaller. For example, neurons $\mathrm{M}_{4}, \mathrm{I}_{3}$, and $\mathrm{I}_{4}$ each reexpressed $\mathrm{NF}$, and adjacent, larger neurons $\mathrm{M}_{1}, \mathrm{I}_{1}$, and $\mathrm{B}_{1}$ did not. Cells of the isthmic reticulospinal group also recovered NF-180, and in fact, expression reached preaxotomy levels in some cells of this group (Fig. 5D). Because neurons recovering NF-180 expression were distributed throughout the brainstem rather than clustered in anatomical or functional groups, it seemed possible that regenerative outcome might determine whether NF was reexpressed. Therefore, giant reticulospinal neurons were divided into two groups on the basis of the probability of their axons regenerating far enough to be labeled by HRP injected $5 \mathrm{~mm}$ caudal to the original hemisection. The patterns of NF-180 expression were then compared. Neurons whose axons regenerated in $<20 \%$ of cases showed no signs of NF recovery by 10 weeks (Fig. $8 A$ ), whereas neurons whose axons extended below the lesion $>80 \%$ of the time had significantly increased NF levels $\left(\chi^{2}=22.97 ; p<0.0001\right) 10$ weeks after transection (Fig. $8 B$ ). Comparison of NF-180 expression level in all identified reticulospinal neurons at 10 weeks versus probability of axonal regeneration showed a strong correlation between recovery of expression and regenerative ability $(r=0.72)$ (Fig. 9). Thus, although all axotomized neurons displayed reduced NF-180 message early after injury, reexpression occurred selectively in neurons capable of regenerating axons through the lesion.

\section{Recovery of NF-180 expression is not dependent on axon growth across lesion}

It has been suggested that after peripheral nerve lesions the reversal of early changes in cytoskeletal gene expression is caused by axon regeneration and reconnection with target cells. Accordingly, it is assumed that the failure of NF to return to normal after axotomy of mammalian central neurons is attributable to failure of regeneration (see Discussion). Because NF-180 gene expression recovers in regenerating lamprey reticulospinal neurons, we tested the hypothesis that this reexpression was a consequence of successful regrowth of axons across the lesion by amputating a segment of spinal cord distal to the transection. Removal of $5 \mathrm{~mm}$ of caudal spinal cord blocked all regeneration of reticulospinal neurons and prevented the behavioral recovery normally seen by 10 weeks. The rostral stump of spinal cord, which contained the 


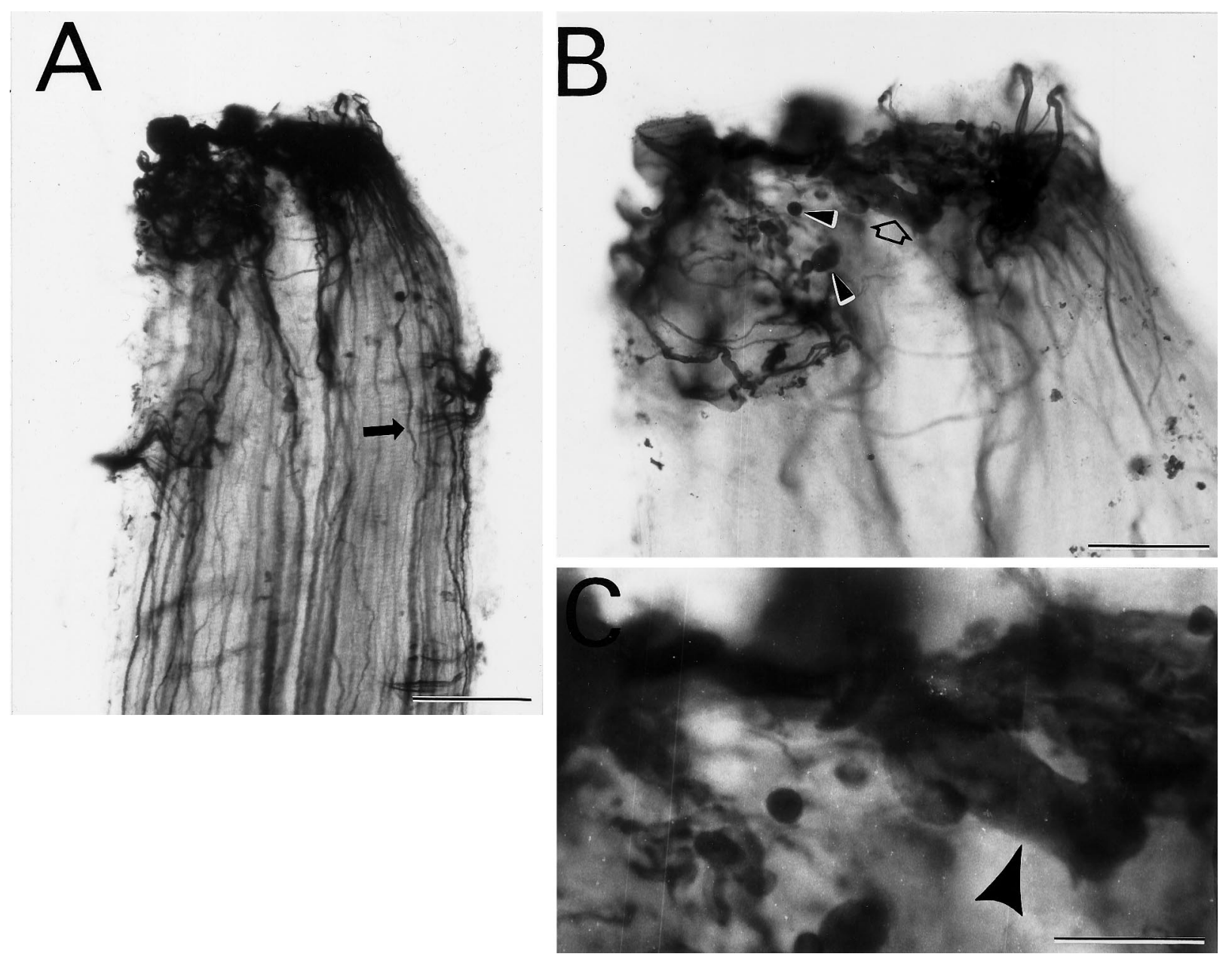

Figure 10. Blockage of axon regeneration by resection of $5 \mathrm{~mm}$ of spinal cord distal to a transection. Immunostaining of proximal spinal cord stump for NF-180 protein after transection and amputation of distal spinal cord. $A$, Whole mount of spinal cord in which regenerating axons are immunostained with LCM3, a mAb that recognizes NF-180 in a phosphorylation-independent manner. Axons (arrow) extend in the correct hemicord without looping. $B$, Higher magnification of the proximal spinal cord stump showing NF-containing bulbous tips of regenerating neurites ( filled arrowheads) terminating abruptly near the cut edge of the stump. Note the enlarged tip of a regenerating axon filled with NFs (open arrow; enlarged further in $C$ and indicated with a large arrowhead). Note also that what at lower magnification appears to be a neuroma at the tip of the rostral stump in $A$ is actually a collection of axon tips engorged with NF-180 protein in $B$. Scale bars: $A, 200 \mu \mathrm{m} ; B, 100 \mu \mathrm{m} ; C, 50 \mu \mathrm{m}$.

dying-back axons of reticulospinal neurons, formed a tapered point without evidence of gliosis or neuroma formation. Axons that had died back during the first 2 weeks regenerated within the proximal stump only as far as the cut end. In whole mounts of spinal cord immunolabeled for total NF with a phosphorylation state-independent monoclonal antibody (mAb) (LCM16), many axons could be seen terminating near the transection site, with little looping or swirling (Fig. 10). Thin neurites characteristic of regenerating reticulospinal axons were seen to extend up to the site of amputation but were not observed to loop or reorient rostralward. Thus, in the absence of a conducive environment for outgrowth, regenerating axons aborted their growth after reaching the rostral end of the resection site.

Prevention of axonal regeneration did not inhibit recovery of NF-180 gene expression. Neurons that reestablished NF-180 expression after spinal transection also recovered expression when regeneration was prevented. Anterior isthmic neurons and neurons $\mathrm{I}_{3}$ and $\mathrm{I}_{4}$, which typically regenerate across a lesion, reexpressed NF-180 at 13 weeks after amputation of distal spinal cord (Fig. 11A,C). NF-180 message remained depressed in neurons that did not recover expression 10 weeks after simple transection
(Figs. 11B,D). The persistence of recovery of NF-180 expression when regeneration is prevented is illustrated quantitatively in Figure 12. Because the gap created by removal of $5 \mathrm{~mm}$ of spinal cord was not traversed by regenerating axons, reexpression of NF-180 at late time points was independent of regrowth into distal targets.

\section{NF-180 protein content increases in reticulospinal neurons during regeneration}

Transection of the spinal cord at the fifth gill amputates $\sim 90 \%$ of the volume of axons belonging to large reticulospinal neurons. NF requirement in the proximal axon stump would be far less than that of an intact axon, and adequate quantities of NF-180 peptide might be produced despite the reduction in the amount of message observed in axotomized neurons. Even if NF demands were higher in regenerating neurites, the lack of demand from the amputated axon could result in adequate production with lower than normal message levels. To evaluate whether reduced levels of NF-180 message after axotomy impair the ability of neurons to maintain adequate levels of NF-180, NF protein content was determined by densitometric scanning of CNS homogenates. NF- 

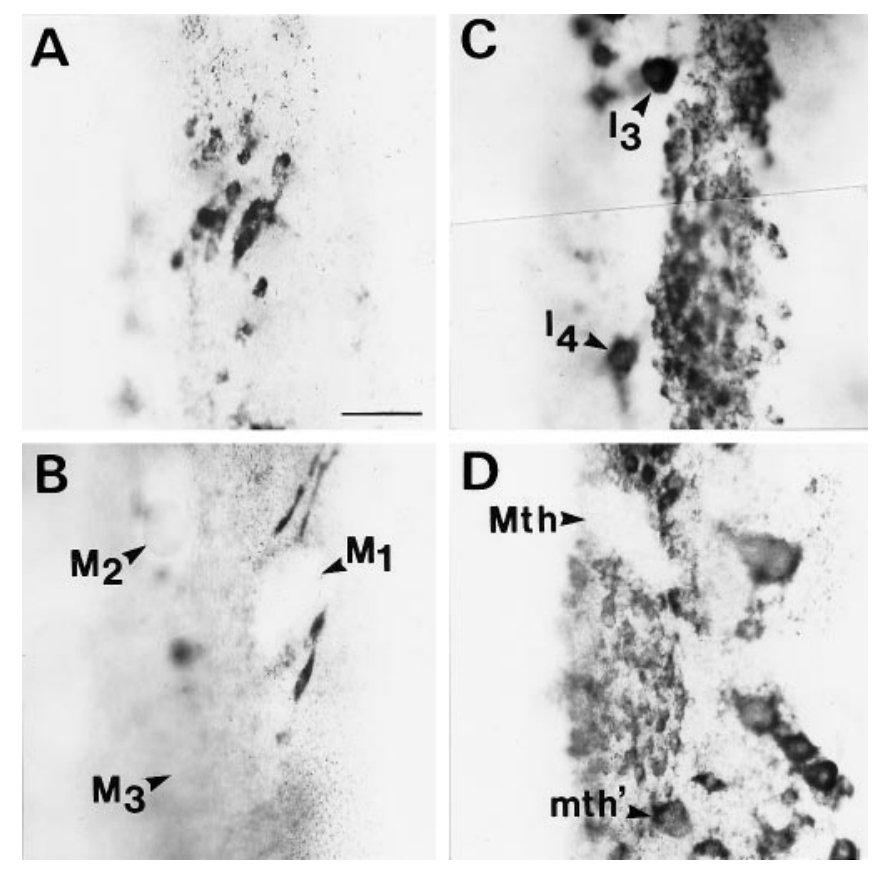

Figure 11. Blocking axonal regeneration does not prevent recovery of NF180 mRNA expression in reticulospinal neurons. Regeneration was prevented by resection of $5 \mathrm{~mm}$ of spinal cord distal to a complete transection as in Figure 10. Message detected by in situ hybridization is shown in a wholemounted brainstem at 13 weeks after transection. Message level has recovered in neurons of the isthmic reticulospinal group $(A)$, identified neurons $\mathrm{I}_{3}$ and $\mathrm{I}_{4}(C)$, and the auxiliary Mauthner neuron $\left(m t h^{\prime}\right)(D)$, but not in the mesencephalic Müller cells $(B)$ or the Mauthner neuron $(M t h)(D)$. This pattern is similar to that observed when regeneration is not prevented.

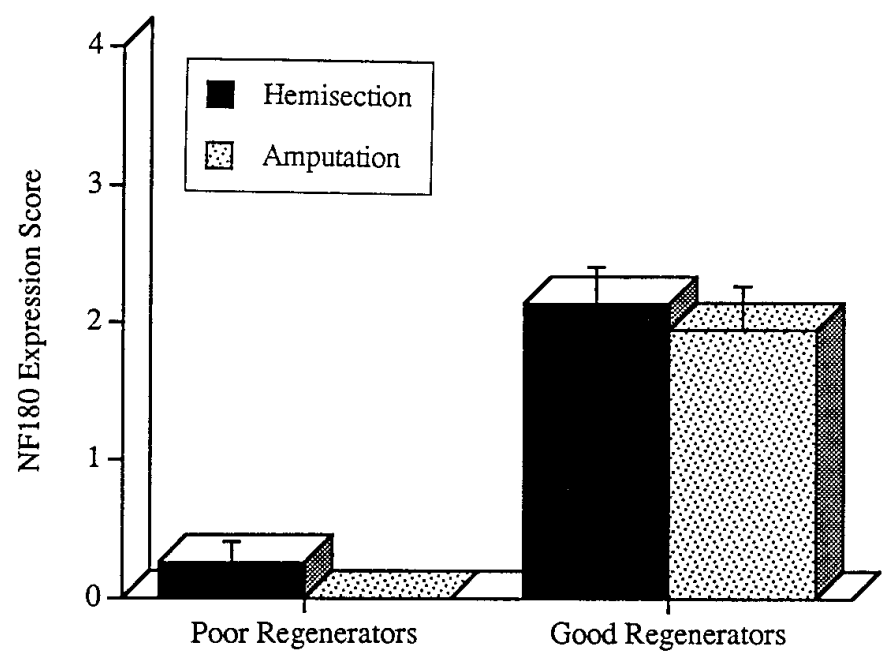

Figure 12. Recovery of NF-180 expression score is unaffected by blocking axonal regeneration. The NF-180 expression scores of four identified neurons whose axons ordinarily regenerate poorly $\left(\leq 20 \% ; \mathrm{M}_{2}, \mathrm{M}_{3}, \mathrm{I}_{1}\right.$, and Mauthner neurons) and four neurons that always regenerated after a hemisection ( $100 \%$; neurons $\mathrm{M}_{4}, \mathrm{I}_{4}, \mathrm{~B}_{2}$, and $\mathrm{B}_{6}$ ) were averaged 10-13 weeks after a spinal hemisection or amputation (see Materials and Methods). The mean NF-180 expression score remained depressed in neurons that ordinarily regenerate poorly (Poor Regenerators, $n=24-27$ neurons), whether regeneration was permitted by spinal hemisection (solid bar) or prevented by spinal cord amputation (dotted bar). Similarly, expression scores recovered in neurons that ordinarily regenerate effectively (Good Regenerators, $n=19-27$ neurons), whether regeneration was permitted (solid bar) or prevented (dotted bar). Error bars represent SEM.
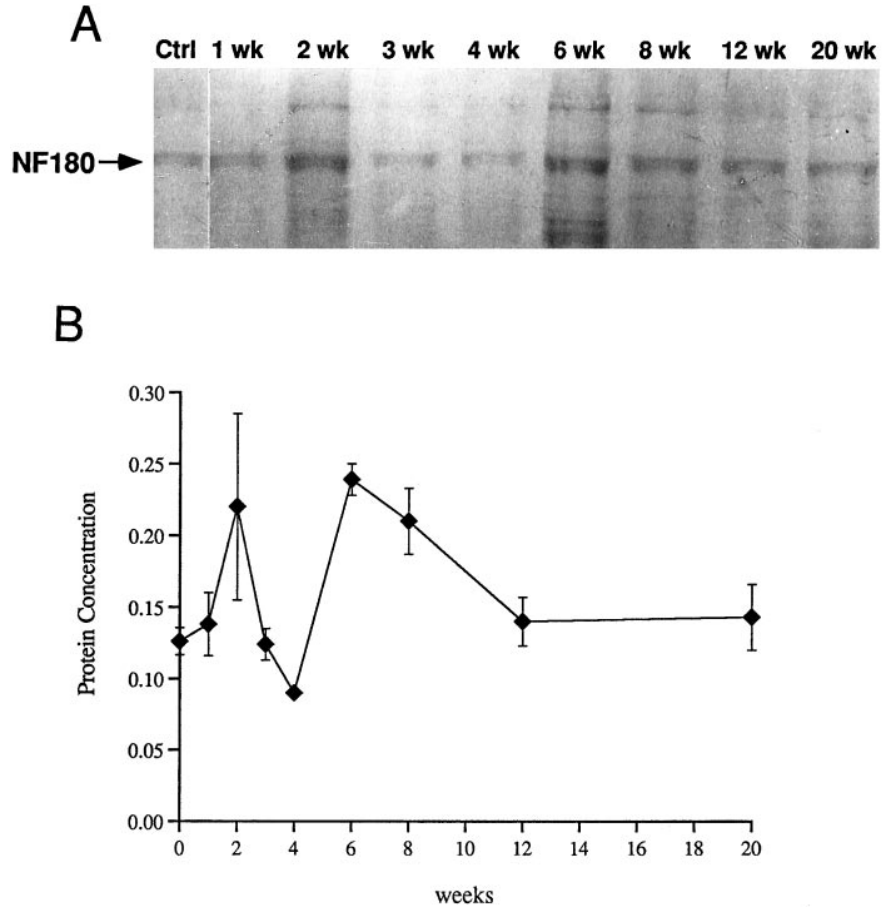

Figure 13. Effect of spinal cord transection on brain NF-180 protein content. $A$, Coomassie blue-stained gels showing NF-180 protein band (arrow) from control brain and from brains at 1, 2, 3, 4, 6, 8, 12, and 20 weeks after complete spinal cord transection. NF-180 is the only protein migrating at $180 \mathrm{kDa}$ in the lamprey brain (Pleasure et al., 1989). $B$, Plot of mean NF-180 protein concentration ( $\mathrm{ng} / 60 \mu \mathrm{g}$ total brain homogenate) \pm SEM after spinal transection ( $n=5$ animals per time point). Coomassie-stained gels were scanned with a Hewlett Packard ScanJet Plus, and protein concentration was determined with Image 5.2 software calibrated to a high molecular weight standard. Despite significant reductions of NF-180 mRNA in axotomized neurons, this protein assay shows that NF-180 level is increased in the brain $6-8$ weeks after axotomy.

180 has been identified as the only component of the prominent $180 \mathrm{kDa}$ band of SDS-PAGE-separated CNS homogenates (Pleasure et al., 1989). This fact allowed direct measurements of NF-180 content by scanning of Coomassie-stained gels. Early fluctuations in brain NF-180 content were followed by a sustained increase at 6 and 8 weeks. A 37\% reduction in NF-180 protein (compared with untransected controls) occurred at 4 weeks, concomitant with the nadir of message expression in axotomized reticulospinal neurons. Protein level subsequently increased to $170 \%$ of control at 6 weeks and returned to preaxotomy level at 12 weeks (Fig. 13). An early increase (56\%) at 2 weeks was also detected but did not reach statistical significance. Immunohistochemistry with a phosphate-independent mAb specific for NF-180 (LCM3) showed further that NF protein content in identified reticulospinal cell bodies was not obviously reduced in transected neurons at 4 or 7 weeks (Fig. 14). These results demonstrate that NF synthesis by axotomized neurons was adequate to supply both cell body and proximal reticulospinal axons up to at least the obex.

\section{DISCUSSION}

\section{Heterogeneity in regeneration is not a function of the extracellular environment}

We have demonstrated a correlation between the regenerative capacity of reticulospinal neurons and their ability to resume expression of NF-180 mRNA after an initial axotomy-induced downregulation. Among the identified reticulospinal neurons, 

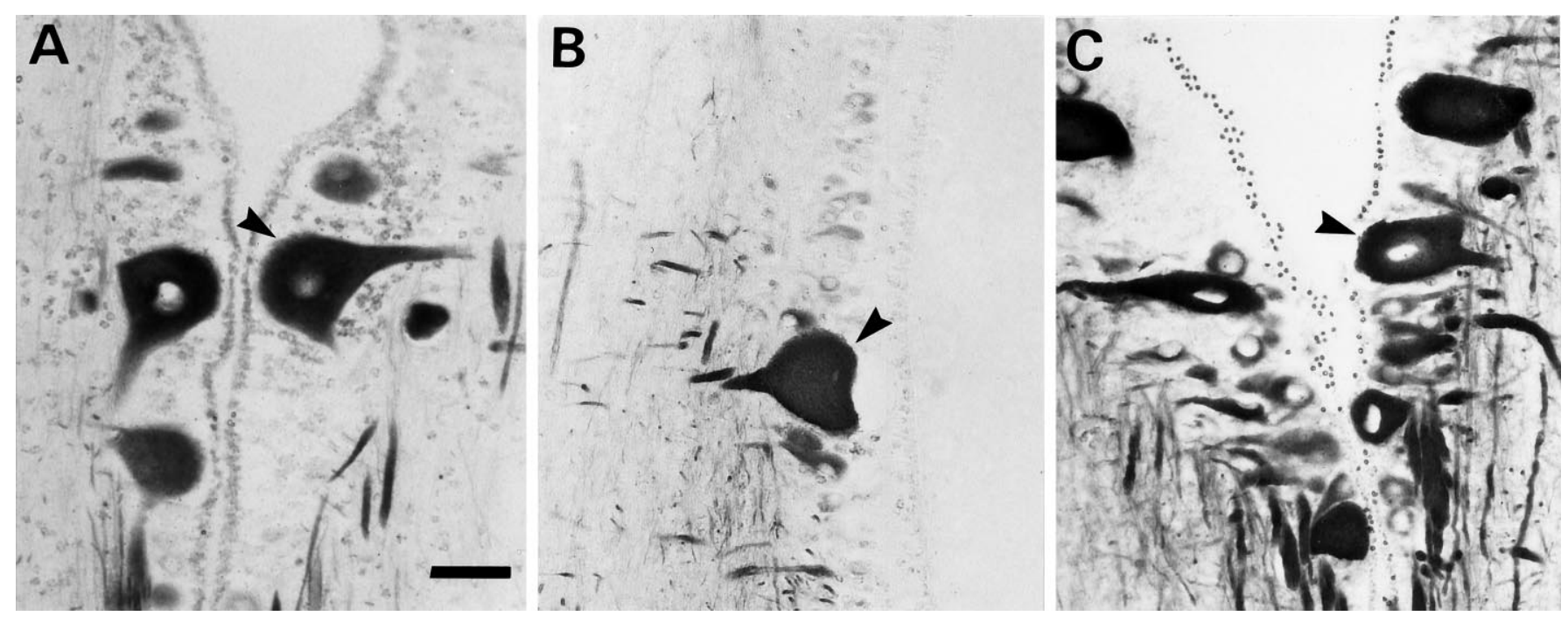

Figure 14. Persistence of high levels of NF-180 protein in giant reticulospinal neurons after axotomy. Paraffin sections were immunostained for total NF-180 with LCM3. $A$, Section through the middle rhombencephalon, showing several giant bulbar reticulospinal neurons in a control lamprey. $B$, A similar section in the anterior rhombencephalon 4 weeks after a complete spinal cord transection. $C$, Section through bulbar reticulospinal neurons at 7 weeks after transection. Note that there is no loss in the intensity of immunostaining, despite the clear reduction in giant reticulospinal neuron NF-180 mRNA illustrated in Figures 4, 6, and 7. Scale bar, $60 \mu \mathrm{m}$.

some regenerated avidly (e.g., $\mathrm{M}_{4}, \mathrm{I}_{3}, \mathrm{~B}_{2}$ ), whereas others did not (e.g., Mauthner, $\left.\mathrm{I}_{1}\right)$. Similar heterogeneity in regenerative ability was reported previously (Swain, 1989; Davis and McClelland, 1994a,b). Regenerating neurites grow through the same scar domain, and axons of both regenerating and nonregenerating neurons project in the same spinal tracts proximal to the transection (Rovainen et al., 1973; Rovainen, 1976; Selzer, 1978; Yin and Selzer, 1983; Lurie and Selzer, 1991a,c). Furthermore, because neurons whose axons regenerated well are located adjacent to neurons whose axons regenerate poorly, the location of the perikaryon did not determine probability of neurite outgrowth. Therefore, heterogeneity in regeneration may reflect intraneuronal differences.

\section{Regenerative capacity is correlated with reexpression of NF-180}

Although NF-180 message levels were reduced in all reticulospinal neurons after spinal transection, the latency, degree, and permanence of the reductions varied. NF gene expression recovered selectively in neurons whose axons regenerate readily, and in these neurons the initial downregulation was often less rapid and less severe than in neighboring neurons that regenerate poorly. NF-180 reexpression occurred at the time when most reticulospinal neurites first appear in the scar: between 4 and 6 weeks after transection (Yin and Selzer, 1983). Appropriate neurons, however, reexpressed NF-180 even when regeneration was blocked by excision of $5 \mathrm{~mm}$ of spinal cord. This recovery of NF expression could not be explained by aberrant axon growth, because most neurites terminated abruptly at the edge of the proximal stump. Thus the secondary upregulation of NF-180 may be part of an intrinsic "regeneration program" that is executed independent of outcome.

\section{Cytoskeletal changes in untransected neurons}

In accurately hemisected animals, NF-180 downregulation was observed in both the axotomized and the unaxotomized Mauthner cell. Bifurcations of giant reticulospinal axons have been described in lamprey, but these are exceptional (Rovainen et al.,
1973). Although lamprey Mauthner cells have one or more medial dendrites that cross the midline, the mutual inhibition seen between Mauthner cells of teleosts is absent in the lamprey (Rovainen, 1967). Nevertheless, these dendrites might mediate transneuronal chemical signals. In other species, morphological and cytoskeletal changes (including axonal sprouting) have been reported in contralateral neurons after nerve injury (Tamaki, 1936; Rotshenker and Tal, 1985; Pearson and Powell, 1986; Pearson et al., 1988; Wong and Oblinger, 1990a).

\section{Downregulation of NF-180 message after axotomy correlates with reduced axon volume}

The level of the spinal cord transection (fifth gill) corresponded to $10 \%$ of total body length. Because Müller and Mauthner neurons project axons nearly the entire length of the spinal cord (Swain et al., 1993), almost $90 \%$ of the total axon volume of these cells was eliminated. During the first 10 weeks after transection, regenerating reticulospinal axons grow up to $9 \mathrm{~mm}$ past the scar, with most growing much less (Rovainen, 1976; Selzer, 1978; Wood and Cohen, 1979; Yin and Selzer, 1983). The regenerated neurites contribute at most an additional $10 \%$ of axon length, generally with greatly reduced diameter. Assuming a constant turnover rate for NF and a constant proportion between the amount of NF message and the rate of protein synthesis, axotomized lamprey reticulospinal neurons would need only $10 \%$ of their pretransection NF mRNA to supply the residual axon with pretransection levels of NF. If NF demand were elevated in regenerating neurons, a fivefold increase in NF message over what is required to supply the residual axon would still appear as a $50 \%$ reduction in NF mRNA content. Consistent with this, we observed a posttransection increase in NF-180 protein content in whole brain homogenates and a persistence of heavy immunolabeling for NF-180 in reticulospinal neurons, despite dramatic reductions in NF-180 message. Similar findings were described in the rat facial nucleus after the facial nerve was sectioned (Tetzlaff et al., 1988). Other studies suggest that after axotomy, NF mRNA expression is influenced by the residual axon volume. When rat optic nerve was 
transected $9 \mathrm{~mm}$ from the eye, NF-M message levels in retina were reduced by $30 \%$ (McKerracher et al., 1993a), whereas transection $0.5 \mathrm{~mm}$ from the retina induced a $50 \%$ reduction in middle molecular weight NF (NF-M) mRNA (McKerracher et al., 1993b). Despite reduced NF message levels, NF transport in regenerating retinal ganglion cell axons was twice that of intact axons (McKerracher et al., 1990). Regeneration of goldfish optic nerve was actually accompanied by an increase in retinal NF mRNA (Tesser et al., 1986). Thus in the lamprey, recovery of NF-180 mRNA expression selectively in reticulospinal neurons that regenerate may well reflect elevated volume-adjusted requirements for NF synthesis in these neurons.

\section{Differences in growth cone morphology between regenerating and developing axons suggest differences in the mechanisms of growth}

Unlike embryonic growth cones, growth cones of regenerating lamprey axons lack filopodia and lamellipodia, have few microfilaments, and are filled with NFs (Lurie et al., 1994; McHale et al., 1995; Pijak et al., 1996), similar to growth cones of regenerating goldfish optic nerve (Lanners and Grafstein, 1980). Simple growth cones without lamellipodia or filopodia have also been described in regenerating optic nerves of frog (Scalia and Matsumoto, 1985) and myelin-deficient rats (Gocht and Löhler, 1993), and in the late-developing corticospinal tract of the rat (Gorgels, 1991). Moreover, a progressive simplification of growth cones has been described during development of the amphibian spinal cord (Nordlander and Singer, 1987).

On the basis of these observations, it would seem that elaborate lamellipodia and filopodia characterize neurons during early development, but growth cones of more mature neurons and those of neurons regenerating within the CNS have a simpler morphology. Perhaps regeneration of CNS axons occurs at a time when developmentally regulated extracellular cues are attenuated and thus relies on mechanisms that are different from those governing early embryonic growth in situ or in tissue culture.

\section{Possible role of NF in regeneration}

The presence of densely packed NFs in the growth cones of regenerating lamprey spinal axons and the selective reexpression of NF-180 mRNA in neurons whose axons regenerate well, even when regeneration is prevented, suggest a possible role for NFs in the mechanism of regeneration. Although NFs have been viewed as relatively static structures, recent evidence suggests a more active role in axon outgrowth. Photobleaching studies of intracellularly injected, fluorescently labeled low molecular weight NF in mouse dorsal root ganglion neurons suggested NF turnover halftimes of $46 \mathrm{~min}$ in quiescent neurites and only $28 \mathrm{~min}$ in growing neurites (Okabe et al., 1993). NFs may even interact with the extracellular environment. In developing chick peripheral nervous system, a phosphorylated NF-M epitope is expressed along the axon beginning at loci of presumed changes in guidance cues (Landmesser and Swain, 1992). Correlations have been noted between the peripherin content of NFs and the rostrocaudal position of rat sympathetic ganglia and intercostal nerves (Kaprielian and Patterson, 1993). Similarly, frog optic axons regenerating into different targets express NFs of different composition (Zhao and Szaro, 1995). Neurites growing in vitro show a distinct tendency to grow straight (Katz, 1985) rather than follow random filopodia. This might be attributable to the straight elongation of a rigid intermediate filament cytoskeleton, because NFs are arrayed in regularly spaced parallel bundles along the length of the axon. Deviation from the straight direction might require a post-translational modification of NFs, such as the phosphorylation of NF-M postulated in developing avian nerves (Landmesser and Swain, 1992).

The preceding observations suggest a possible role for NFs in steering axonal growth or in consolidating directional decisions. They do not implicate NFs directly in the mechanism of growth cone extension or explain why NF-180 expression might be increased selectively in regenerating neurons. Intracellular injections of antibodies to NF into Xenopus embryos (Szaro et al., 1991) or embryonic Xenopus neurons in vitro (Lin and Szaro, 1994) resulted in inhibition of NF formation and axon development. A similar effect was observed when mRNA encoding a truncated form of NF-M was injected into Xenopus embryos (Lin and Szaro, 1996). On the other hand, in NF-deficient transgenic mice (Schmidt and Plurad, 1985) and NF-deficient "quiverer" quail mutants (Yamasaki et al., 1991; Ohara et al., 1993), axons of attenuated caliber can develop. Thus it is not yet clear whether NFs are involved in the mechanism of embryonic axon elongation. In regenerating lamprey growth cones, NFs are present in swirls rather than parallel longitudinal arrays (Lurie et al., 1994; McHale et al., 1995; Pijak et al., 1996) and despite being highly phosphorylated (Hall et al., 1991; Pijak et al., 1996) are more densely packed than they are in the axon (Pijak et al., 1996). Thus they may be under increased pressure, suggesting that transport of NFs into the injured axon tip may provide an internal propulsive force driving the growth cone forward. This is also suggested by the similar appearance of swollen NF-packed growth cones when regeneration was frustrated, both in the present study and in ligated peripheral nerve (Schmidt and Plurad, 1985).

\section{REFERENCES}

Bates CA, Meyer RL (1993) The heavy neurofilament protein is expressed in regenerating adult but not embryonic mammalian optic fibers in vitro. Exp Neurol 119:249-257.

Bovalenta P, Mason C (1987) Growth cone morphology varies with position in the developing mouse visual pathway from retina to first targets. J Neurosci 7:1447-1460.

Bovalenta P, Dodd J (1990) Guidance of commissural growth cones at the floor plate in embryonic rat spinal cord. Development 109:435-447.

Bradford MM (1976) A rapid and sensitive method for the quantitation of microgram quantities of protein utilizing the principle of protein-dye binding. Anal Biochem 72:248-254.

Cohen AH, Mackler SA, Selzer ME (1988) Functional regeneration following spinal transection demonstrated in the isolated spinal cord of the larval sea lamprey. Proc Natl Acad Sci USA 83:2763-2766.

Currie SN, Ayers J (1983) Regeneration of locomotor command systems in the sea lamprey. Brain Res 279:238-240.

Davis GR, McClellan AD (1993) Time course of anatomical regeneration of descending brainstem neurons and behavioral recovery in spinaltransected lamprey. Brain Res 602:131-137.

Davis GR, McClelland, AD (1994a) Extent and time course of restoration of descending brainstem projections in spinal cord-transected lamprey. J Comp Neurol 344:65-82.

Davis GR, McClelland AD (1994b) Long distance axonal regeneration of identified lamprey reticulospinal neurons. Exp Neurol 127:94-105.

Glasgow E, Druger RK, Fuchs C, Lane WS, Schechter N (1994) Molecular cloning of gefiltin (ON1): serial expression of two new neurofilament mRNAs during optic nerve regeneration. EMBO J 13:297-305.

Gocht A, Löhler J (1993) Microenvironmental changes during axonal regrowth in the optic nerve of the myelin deficient rat: immunocytochemical and ultrastructural observations. J Neurocytol 22:461-479.

Goldstein ME, Weiss SR, Lazzarini RA, Shneidman PS, Lees JF, Schlaepfer WW (1988) mRNA levels of all three neurofilament proteins decline following nerve transection. Brain Res 427:287-291.

Gordon-Weeks PR (1989) Growth at the growth cone. Trends Neurosci 12:238-40.

Gorgels TG (1991) Outgrowth of the pyramidal tract in the rat cervical 
spinal cord: growth cone ultrastructure and guidance. J Comp Neurol 306:95-116.

Hall GF, Lee VM-Y (1995) Neurofilament sidearm proteolysis is a prominent early effect of axotomy in lamprey giant central neurons. J Comp Neurol 0353:38-49.

Hall GF, Lee VM-Y, Kosik KS (1991) Microtubule destabilization and neurofilament phosphorylation precede dendritic sprouting after close axotomy of lamprey central neurons. Proc Natl Acad Sci USA 88:5016-5020.

Ho RK, Goodman CS (1982) Peripheral pathways are pioneered by an array of central and peripheral neurones in grasshopper embryos. Nature 297:404-406.

Hoffman PN, Cleveland DW (1988) Neurofilament and tubulin expression recapitulates the developmental program during axonal regeneration: induction of a specific beta-tubulin isotype. Proc Natl Acad Sci USA 85:4530-4533.

Hoffman PN, Thompson GW, Griffin JW, Price DL (1985) Changes in neurofilament transport coincide temporally with alterations in the caliber of axons in regenerating motor fibers. J Cell Biol 101:1332-1340.

Hoffman PN, Pollock SC, Striph GG (1993) Altered gene expression after optic nerve transection: reduced neurofilament expression as a general response to axonal injury. Exp Neurol 119:32-36.

Jacobs AJ, Kamholz J, Selzer ME (1995a) The single lamprey neurofilament subunit (NF-180) lacks multiphosphorylation repeats and is expressed selectively in projection neurons. Mol Brain Res 29:43-52.

Jacobs AJ, Swain GP, Selzer ME (1995b) Developmental increases in expression of neurofilament mRNA selectively in projection neurons of the lamprey CNS. J Comp Neurol 364:383-401.

Jiang YQ, Pickett J, Oblinger MM (1994) Comparison of changes in beta-tubulin and NF gene expression in rat DRG neurons under regeneration-permissive and regeneration-prohibitive conditions. Brain Res 637:233-241.

Kaprielian Z, Patterson P (1993) Surface and cytoskeletal markers of rostrocaudal position in mammalian nervous system. J Neurosci 13:2495-2508.

Katz MJ (1985) How straight do axons grow? J Neurosci 5:589-595.

Kendrick NC, Johansen JJ, Lee PR, Santek DA (1994) Optimization of an HP scanjet for quantification of protein electrophoresis gels. Anal Biochem 219:297-304.

Keshishian H, Bentley D (1983) Embryogenesis of peripheral nerve pathways in grasshopper legs. I. The initial pathway to the CNS. Dev Biol 96:89-102.

Landmesser L, Swain S (1992) Temporal and spatial modulation of a cytoskeletal antigen during peripheral axonal pathfinding. Neuron 8:291-305.

Lanners HN, Grafstein B (1980) Early stages of axonal regeneration in the goldfish optic tract: an electron microscopic study. J Neurocytol 9:733-751.

Lee VM-Y, Carden MJ, Schlaepfer WW (1986) Structural similarities and differences between neurofilament proteins from five different species as revealed using monoclonal antibodies. $J$ Neurosci 6:2179-2186

Letourneau PC (1981) Immunohistochemical evidence for colocalization in neurite growth cones of actin and myosin and their relationship to cell-substratum adhesions. Dev Biol 85:113-122.

Lin CH, Forscher P (1995) Growth cone advance is inversely proportional to retrograde F-actin flow. Neuron 14:763-771.

Lin W, Szaro BG (1994) Maturation of neurites in mixed cultures of spinal cord neurons and muscle cells from Xenopus laevis embryos followed with antibodies to neurofilament proteins. J Neurobiol 25:1235-1248.

Lin W, Szaro BG (1996) Effects of intermediate filament disruption on the early development of the peripheral nervous system of Xenopus laevis. Dev Biol 179:197-211.

Lin CH, Espreafico EM, Mooseker MS, Forscher P (1996) Myosin drives retrograde F-actin flow in neuronal growth cones. Neuron 16:769-782.

Lurie DI, Selzer ME (1991a) Axonal regeneration in the adult lamprey spinal cord. J Comp Neurol 306:409-416.

Lurie DI, Selzer ME (1991b) The need for cellular elements during axonal regeneration in the sea lamprey spinal cord. Exp Neurol 112:64-71.

Lurie DI, Selzer ME (1991c) Preferential regeneration of spinal axons through the scar in hemisected lamprey spinal cord. J Comp Neurol 313:669-679.

Lurie DI, Pijak DS, Selzer ME (1994) Structure of reticulospinal axon growth cones and their cellular environment during regeneration in the lamprey spinal cord. J Comp Neurol 344:559-580.

Mackler SA, Selzer ME (1987) Specificity of synaptic regeneration in the spinal cord of the larval sea lamprey. J Physiol (Lond) 388:183-198.

Mackler SA, Yin HS, Selzer ME (1986) Determinants of directional specificity in the regeneration of lamprey spinal axons. J Neurosci 6:1814-1821.

McHale MK, Hall GF, Cohen MJ (1995) Early cytoskeletal changes following injury of giant spinal axons in the lamprey. J Comp Neurol 353:25-37.

McKerracher L, Vidal SM, Aguayo AJ (1990) Slow transport rates of cytoskeletal proteins change during regeneration of axotomized retinal neurons in adult rats. J Neurosci 10:641-648.

McKerracher L, Essagian C, Aguayo AJ (1993a) Temporal changes in $\beta$-tubulin and neurofilament mRNA levels after transection of adult rat retinal ganglion cell axons in the optic nerve. J Neurosci 13:2617-2626.

McKerracher L, Essagian C, Aguayo AJ (1993b) Marked increase in $\beta$-tubulin mRNA expression during regeneration of axotomized retinal ganglion cells in adult mammals. J Neurosci 13:5294-5300.

Mikucki SA, Oblinger MM (1991) Corticospinal neurons exhibit a novel pattern of cytoskeletal gene expression after injury. J Neurosci Res 30:213-225.

Muma NA, Hoffman PN, Slunt HH, Applegate MD, Lieberburg I, Price DL (1990) Alterations in levels of mRNAs coding for neurofilament protein subunits during regeneration. Exp Neurol 107:230-235.

Nordlander RH, Singer M (1987) Axonal growth cones in the developing amphibian spinal cord. J Comp Neurol 263:485-496.

Oblinger MM, Lasek RJ (1988) Axotomy-induced alterations in the synthesis, transport of neurofilaments and microtubules in dorsal root ganglion cells. J Neurosci 8:1747-1758.

Ohara O, Gahara Y, Miyake T, Teraoka H, Kitamura T (1993) Neurofilament deficiency in quail caused by nonsense mutation in neurofilament-L gene. J Cell Biol 121:387-395.

Okabe S, Miyasaka H, Hirokawa N (1993) Dynamics of the neuronal intermediate filaments. J Cell Biol 121:375-386.

Pearson RCA, Powell TPS (1986) Hypertrophy of motor neurons in the oculomotor nucleus of the rat following removal of the contralateral extraocular muscles. Brain Res 382:184-192.

Pearson RCA, Taylor N, Snyder SH (1988) Tubulin messenger RNA: in situ hybridization reveals bilateral increases in hypoglossal and facial nuclei following nerve transection. Brain Res 463:245-249.

Pijak DS, Hall GF, Tenicki PJ, Boulos AS, Lurie DI, Selzer ME (1996) Neurofilament spacing, phosphorylation, and axon diameter in regenerating and uninjured lamprey axons. J Comp Neurol 368:569-581.

Pleasure SJ, Selzer ME, Lee VM-Y (1989) Lamprey neurofilaments combine in one subunit the features of each mammalian NF triplet protein but are highly phosphorylated only in large axons. J Neurosci 9:698-709.

Rotshenker S, Tal M (1985) The transneuronal induction of sprouting and synapse formation in intact mouse muscles. J Physiol (Lond) 360:387-396.

Rovainen CM (1967) Physiological and anatomical studies on large neurons of the central nervous system of the sea lamprey (Petromyzon marinus). I. Müller and Mauthner cells. J Neurophysiol 30:1000-1023.

Rovainen CM (1976) Regeneration of Müller and Mauthner axons after spinal transection in larval lampreys. J Comp Neurol 168:545-554.

Rovainen CM, Johnson PA, Roach EA, Mankovsky JA (1973) Projections of individual axons in lamprey spinal cord determined by tracings through serial sections. J Comp Neurol 149:193-202.

Scalia F, Matsumoto DE (1985) The morphology of growth cones of regenerating optic nerve axons. J Comp Neurol 231:323-338.

Schmidt RE, Plurad SB (1985) Ultrastructural appearance of intentionally frustrated axonal regeneration in rat sciatic nerve. $J$ Neuropathol Exp Neurol 44:130-146.

Selzer ME (1978) Mechanisms of functional recovery and regeneration after spinal cord transection in larval sea lamprey. J Physiol (Lond) 277:395-408.

Swain GP (1989) CNS regeneration and behavioral recovery following spinal cord transection in the sea lamprey Petromyzon marinus. $\mathrm{PhD}$ thesis, Northeastern University.

Swain GP, Snedeker JA, Ayers J, Selzer ME (1993) The cytoarchitecture of spinal-projecting neurons in the brain of the larval sea lamprey. J Comp Neurol 336:194-210.

Swain GP, Jacobs AJ, Frei E, Selzer ME (1994) A method for in situ 
hybridization in wholemounted lamprey brain: neurofilament expression in larvae and adults. Exp Neurol 126:256-269.

Szaro BG, Grant P, Lee VM-Y, Gainer H (1991) Inhibition of axonal development after injection of neurofilament antibodies into a Xenopus laevis embryo. J Comp Neurol 308:576-585.

Tamaki K (1936) Further studies on the effect of section of one peroneal nerve of the albino rat on the intact nerve of the opposite side. J Comp Neurol 64:437-448.

Tesser P, Jones PS, Schechter N (1986) Elevated levels of retinal neurofilament mRNA accompany optic nerve regeneration. J Neurochem 47:1235-1243.

Tetzlaff W, Bisby MA, Kreutzberg GW (1988) Changes in cytoskeletal proteins in the rat facial nucleus following axotomy. J Neurosci 8:3181-3189.

Tetzlaff W, Alexander SW, Miller FD, Bisby MA (1991) Response of facial and rubrospinal neurons to axotomy: changes in mRNA expression for cytoskeletal proteins and GAP-43. J Neurosci 11:2528-2544.

Tosney K, Landmesser L (1985) Growth cone morphology and trajectory in the lumbosacral region of the chick embryo. J Neurosci 5:2345-2358.

Wong J, Oblinger MM (1990a) A comparison of peripheral and central axotomy effects on neurofilament and tubulin gene expression in rat dorsal root ganglion neurons. J Neurosci 10:2215-2222.

Wong J, Oblinger MM (1990b) Differential regulation of peripherin and neurofilament gene expression in regenerating rat DRG neurons. J Neurosci Res 27:332-341.

Wood MR, Cohen MJ (1979) Synaptic regeneration in identified neurons of the lamprey spinal cords. Science 206:344-347.

Wood MR, Cohen MJ (1981) Synaptic regeneration and glial reactions in the transected spinal cord of the lamprey. J Neurocytol 10:57-79.

Yaginuma H, Homma S, Kunzi R, Oppenheim RW (1991) Pathfinding by growth cones of commissural interneurons in the chick embryo spinal cord: a light and electron microscopic study. J Comp Neurol 304:78-102.

Yamasaki H, Itakura C, Mizutani M (1991) Hereditary hypotrophic axonopathy with neurofilament deficiency in a mutant strain of the Japanese quail. Acta Neuropathol (Berl) 82:427-434.

Yin HS, Selzer ME (1983) Axonal regeneration in lamprey spinal cord. J Neurosci 3:1135-1144.

Yin HS, Selzer ME (1984) Electrophysiologic evidence of regeneration of lamprey spinal neurons. Exp Neurol 83:618-628.

Yin HS, Mackler SA, Selzer ME (1984) Directional specificity in the regeneration of lamprey spinal axons. Science 224:894-896.

Zhao Y, Szaro BG (1995) The optic tract and tectal ablation influence the composition of neurofilaments in regenerating optic axons of $\mathrm{Xe}$ nopus laevis. J Neurosci 15:4629-4640. 